\title{
Age constraint for the Moreno Hill Formation (Zuni Basin) by CA-TIMS and LA-ICP-MS detrital zircon geochronology
}

\author{
Charl D Cilliers ${ }^{\text {Corresp., } 1}$, Ryan T Tucker ${ }^{1}$, James L Crowley ${ }^{2}$, Lindsay E Zanno ${ }^{3,4}$ \\ ${ }^{1}$ Department of Earth Sciences, Faculty of Science, University of Stellenbosch, Stellenbosch, Western Cape, South Africa \\ 2 Department of Geosciences, Boise State University, Boise, Idaho, United States of America \\ 3 Paleontology, North Carolina Museum of Natural Sciences, Raleigh, North Carolina, United States of America \\ 4 Department of Biological Sciences, North Carolina State University, Raleigh, North Carolina, United States of America \\ Corresponding Author: Charl D Cilliers \\ Email address: cdcilliers@sun.ac.za
}

The "mid-Cretaceous" ( 125 - $80 \mathrm{Ma}$ ) was punctuated by major plate-tectonic upheavals resulting in widespread volcanism, mountain-building, eustatic sea-level changes, and climatic shifts that together had a profound impact on terrestrial biotic assemblages. Paleontological evidence suggests terrestrial ecosystems underwent a major restructuring during this interval, yet the pace and pattern are poorly constrained. Current impediments to piecing together the geologic and biological history of the "mid-Cretaceous" include a relative paucity of terrestrial outcrop stemming from this time interval, coupled with a historical understudy of fragmentary strata. In the Western Interior of North America, sedimentary strata of the Turonian - Santonian stages are emerging as key sources of data for refining the timing of ecosystem transformation during the transition from the late-Early to early-Late Cretaceous. In particular, the Moreno Hill Formation (Zuni Basin, New Mexico) is especially important for detailing the timing of the rise of iconic Late Cretaceous vertebrate faunas. This study presents the first systematic geochronological framework for key strata within the Moreno Hill Formation. Based on the double-dating of (U-Pb) detrital zircons, via CA-TIMS and LA-ICP-MS, we interpret two distinct depositional phases of the Moreno Hill Formation (initial deposition after 90.9 Ma [middle Turonian] and subsequent deposition after 88.6 Ma [early Coniacian]), younger than previously postulated based on correlations with marine biostratigraphy. Sediment and the cooccurring youthful subset of zircons are sourced from the southwestern Cordilleran Arc and Mogollon Highlands, which fed into the landward portion of the Gallup Delta (the Moreno Hill Formation) via northeasterly flowing channel complexes. This work greatly strengthens linkages to other early Late Cretaceous strata across the Western Interior. 


\section{Age constraint for the Moreno Hill Formation (Zuni Basin) by CA-TIMS and LA-ICP-MS}

\section{2 detrital zircon geochronology}

3

4 Charl D. Cilliers ${ }^{1}$; Ryan T. Tucker ${ }^{1}$; James L. Crowley ${ }^{2}$; Lindsay E. Zanno ${ }^{3,4}$

5

6

$7{ }^{1}$ Department of Earth Sciences, Faculty of Science, University of Stellenbosch, Private Bag X1,

8 Matieland 7602, South Africa

92 Department of Geosciences, Boise State University, Boise, Idaho 83725, USA

$10{ }^{3}$ Paleontology, North Carolina Museum of Natural Sciences, 11 W. Jones St., Raleigh, NC

$11 \quad 2.7601$, USA

$12{ }^{4}$ Department of Biological Sciences, Campus Box 7617, North Carolina State University,

13 Raleigh, North Carolina 27695, USA

15 Corresponding Author: Charl Cilliers ${ }^{1}$

16 Department of Earth Sciences, Faculty of Science, University of Stellenbosch, Private Bag X1,

17 Matieland 7602, South Africa

18 E-mail address: cdcilliers@sun.ac.za 


\section{Abstract}

The "mid-Cretaceous" ( 125-80 Ma) was punctuated by major plate-tectonic

27 upheavals resulting in widespread volcanism, mountain-building, eustatic sea-level changes, and

28 climatic shifts that together had a profound impact on terrestrial biotic assemblages.

29 Paleontological evidence suggests terrestrial ecosystems underwent a major restructuring during

30 this interval, yet the pace and pattern are poorly constrained. Current impediments to piecing

31 together the geologic and biological history of the "mid-Cretaceous" include a relative paucity of

32 terrestrial outcrop stemming from this time interval, coupled with a historical understudy of

33 fragmentary strata. In the Western Interior of North America, sedimentary strata of the Turonian

34 - Santonian stages are emerging as key sources of data for refining the timing of ecosystem

35 transformation during the transition from the late-Early to early-Late Cretaceous. In particular,

36 the Moreno Hill Formation (Zuni Basin, New Mexico) is especially important for detailing the

37 timing of the rise of iconic Late Cretaceous vertebrate faunas. This study presents the first

38 systematic geochronological framework for key strata within the Moreno Hill Formation. Based

39 on the double-dating of (U-Pb) detrital zircons, via CA-TIMS and LA-ICP-MS, we interpret two

40 distinct depositional phases of the Moreno Hill Formation (initial deposition after 90.9 Ma

41 [middle Turonian] and subsequent deposition after 88.6 Ma [early Coniacian]), younger than

42 previously postulated based on correlations with marine biostratigraphy. Sediment and the co-

43 occurring youthful subset of zircons are sourced from the southwestern Cordilleran Arc and

44 Mogollon Highlands, which fed into the landward portion of the Gallup Delta (the Moreno Hill

45 Formation) via northeasterly flowing channel complexes. This work greatly strengthens linkages

46 to other early Late Cretaceous strata across the Western Interior. 
47

48

49

50

51

52

53

54

55

56

57

58

\section{Introduction}

The Moreno Hill Formation (Zuni Basin, New Mexico) provides an important snapshot of North America's late-Early to early-Late Cretaceous Mesozoic sediment history. The Moreno Hill Formation and the larger Zuni Basin (Fig. 1) document a dynamic period of tectonic upheaval, active volcanism, greenhouse climate, and an ever-changing coastal margin in North America (Kauffman \& Hart, 1996; Lloyd et al., 2008; Benton, 2009; Chaboureau et al., 2014; Haq, 2014; Huber et al., 2018). Specifically, the western margin of the Western Interior Seaway underwent significant shifts in coastal morphology and coupled with on-going tectonism resulted in numerous unconformities, lateral discontinuities, and cryptic or tenuous stratigraphic linkages (Molenaar, 1983a; Molenaar et al., 2002; Haq, 2014; Albright \& Titus, 2016; D’Emic et al., 2019). Although a number of studies have sought to resolve these complexities by obtaining depositional ages via radiometric age dating, the "mid-Cretaceous" southwestern shoreline (New Mexico) of the Western Interior Seaway has largely gone underexplored (Lawton \& Bradford, 2011; Meyers et al., 2012; Roberts et al., 2013; Barclay et al., 2015; Juárez-Arriaga et al., 2019; Lawton, 2019; Laurin et al., 2019; Pană, Poulton \& DuFrane, 2019; Rinke-Hardekopf, Dashtgard \& MacEachern, 2019). Adjacent basins offer little aid as lithostratigraphic relationships become increasingly cryptic (Albright \& Titus, 2016; D’Emic et al., 2019; Tucker et al., 2020).

Furthermore, recent studies have sought to address the variable relationship of volcaniclastic (primary-deposit) and volcanilithic (secondary-deposit) rock used to date sedimentary sequences (Rossignol et al., 2018; Tucker et al., 2020). This is increasingly important, particularly when detangling the complexities of Maximum Depositional Ages (MDAs) and ecosystem evolution within terrestrial depo-centers that are marine-adjacent, including possible linkages to the Gallup Delta (Jinnah et al., 2009; Chure et al., 2010; Irmis et 
70 al., 2011; Ross et al., 2017; Coutts, Matthews \& Hubbard, 2019; Herriott et al., 2019; Lin \&

71 Bhattacharya, 2019; Lin, Bhattacharya \& Stockford, 2019; Joeckel et al., 2020; Tucker et al., 72 2020).

Based on established linkages to marine biostratigraphic records tied to radiometric dates derived from co-occurring bentonites, previously reported ages for the terrestrial Moreno Hill Formation place its deposition entirely within the Turonian (McLellan et al., 1983a; Wolfe \& Kirkland, 1998; Molenaar et al., 2002; McDonald, Wolfe \& Kirkland, 2006, 2010; Fowler, 2017); yet, based on stratigraphic position (overlying the Atarque Sandstone) the Moreno Hill Formation was temporally assigned to the middle to upper Turonian (Pike, 1947; McLellan et al., 1983a; Wolfe \& Kirkland, 1998; McDonald, Wolfe \& Kirkland, 2006, Fig. 1, p. 278;

McDonald, Wolfe \& Kirkland, 2010). More recently, Chin et al. (2019) noted the possibility that the uppermost Moreno Hill may be younger than Turonian. biozone coupled with the occurrence of the middle Turonian ammonite Collignoniceras woollgari woollgari and a Mytiloides bivalve (reported as either M. labiatus or M. mytiloides)

85 (Cobban, 1983; Wolfe \& Kirkland, 1998; Kirkland, Smith \& Wolfe, 2005). The emplacement of sediment into the Atarque archive is documented to have occurred during a "local" regressional

87 phase linked to the tectonic influence of the ancestral Mogollon Highlands, predating the regional Western Interior Seaway regression (Wolfe, 1989; Elder \& Kirkland, 1993; Molenaar, 1983a; Elder \& Kirkland, 1994; Wolfe \& Kirkland, 1998; Hook \& Cobban, 2013). In

90 establishing age constraints for the Moreno Hill Formation, Wolfe \& Kirkland (1998, Fig. 3, p.

91306 , modified from Obradovich, 1993) rely on ${ }^{40} \mathrm{Ar} /{ }^{39} \mathrm{Ar}$ dates linked to ammonite

92 biostratigraphic zones. Re-calibrations of these dates (from the Ferron Sandstone, the lower 
93 Juana Lopez beds of the D-Cross Tongue of the Mancos Shale, and from the Marias River Shale)

94 place the Moreno Hill Formation between $91.1 \pm 0.5 \mathrm{Ma}$ (Prionocyclus hyatti) and $88.9 \pm 0.6 \mathrm{Ma}$

95 (Scaphites preventricosus) (Fowler, 2017). In spite of this biostratigraphic framework,

96 correlation between terrestrial and marine sequences is challenging. Whilst the Western Interior

97 Seaway has produced one of the most robust marine biostratigraphic frameworks in the world

98 (Obradovich, 1993; Cobban et al., 2006), pervasive inconsistencies between key terrestrial

99 sediment archives remain a major obstacle (Cifelli et al., 1997, 1999; Albright \& Titus, 2016;

100 D’Emic et al., 2019).

101 Confident age constraints for the Moreno Hill Formation are key to detailing patterns of

102 vertebrate evolution and biostratigraphy in the early-Late Cretaceous given its well-preserved

103 floral (angiosperm, gymnosperm) and faunal (osteichthyan fish, squamate, trionychid,

104 crocodilian, dinosaurian and mammalian) assemblages (Wolfe et al., 1997; Wolfe \& Kirkland,

105 1998; Kirkland \& Wolfe, 2001; McDonald, Wolfe \& Kirkland, 2006; Wolfe et al., 2007;

106 Sweeney et al., 2009; McDonald, Wolfe \& Kirkland, 2010; Wolfe \& Wolfe, 2016; Chin et al.,

107 2019; Nesbitt et al., 2019). Whilst previously identified ash beds (tonstein or paratonstein

108 [Admakin, 2001]) occur within its coal seams (Hoffman, 1996), these are stratigraphically

109 limited to the lower portions of the formation. To provide broader context, we focused on

110 utilizing U-Pb detrital geochronology on suspected near-syndepositional igneous (well-faceted)

111 zircon grains from channel sandstone deposits in the key members spanning the Moreno Hill

112 Formation. The well-documented detrital zircon record of the Western Interior is a crucial

113 foundation to assess likely source terranes for these grains that are likely derived from various

114 volcanic inliers of the westerly-adjacent Cordilleran Volcanic Arc (Willis, 1999; Dickinson \&

115 Gehrels, 2003; DeCelles, 2004; Dickinson \& Gehrels, 2009a, 2009b; Laskowski, DeCelles \& 
116 Gehrels, 2013). By assessing the zircon age spectra via Laser Ablation-Inductively Coupled

117 Plasma-Mass Spectrometry (LA-ICP-MS) and subsequently dating the youngest grains via

118 Chemical Abrasion Isotope Dilution Thermal Ionization Mass Spectrometry (CA-TIMS), this

119 study provides the needed MDAs that the Moreno Hill Formation is currently lacking. With

120 these MDAs we are be able to 1) refine the depositional age and duration of sedimentation of the

121 Moreno Hill Formation; 2) provide newly calibrated linkages based on the revised temporal

122 framework; and 3) determine likely source terranes and provide a reliable reconstruction for its

123 emplacement. This refined temporal context will provide crucial context for paleobiogeographic

124 and macroevolutionary studies involving terrestrial vertebrate assemblages during the mid-

125 Cretaceous.

$126 \quad$ Background

127 Subduction of the Farallon Plate under North America during the Middle Jurassic to

128 Early Cenozoic, resulted in the Cordilleran Magmatic Arc (Miall et al., 2008; DeCelles \&

129 Graham, 2015). This, in turn, resulted in thin-skinned thrusts of the Sevier Orogeny and the

130 Western Interior Basin, which was subsequently flooded by a vast epicontinental seaway for

131 much of the Cretaceous (Kauffman \& Caldwell, 1993; Miall et al., 2008; DeCelles \& Graham,

132 2015). Subduction angles shallowed during the Late Campanian (Laramide Orogeny) resulting in

133 partitioning of the Western Interior Basin into a mosaic of sub-basins preserving variable

134 paleoenvironmental archives (Kauffman \& Caldwell, 1993; Miall et al., 2008; Titus, Roberts \&

135 Albright, 2013; Lawton, 2019). Alluvial sediments within these basins contain siliciclastic,

136 volcanic, and plutonic detritus from the westerly Cordilleran and Sevier orogenic processes and

137 from the Mogollon Highlands to the south, a topographic feature uplifted during several 
138 Mesozoic tectonic events (Cumella, 1983; Molenaar, 1983a; Kauffman, 1984; Bilodeau, 1986;

139 Dickinson \& Gehrels, 2008; Salem, 2009; Miall \& Catuneanu, 2019).

140 Transgressive-regressive cycles of the Western Interior Seaway, including the Greenhorn

141 and Niobrara cyclothems, then greatly affected the extent and character of coastal habitats

142 (Kauffman, 1969, 1977; Molenaar, 1983a; Kauffman, 1984; McDonough \& Cross, 1991;

143 Kauffman \& Caldwell, 1993; Roberts \& Kirschbaum 1995; Miall \& Catuneanu, 2019).

144 The Moreno Hill Formation is preserved in the Laramidian Zuni Basin, located between

145 the Nutria Monocline, Zuni and Defiance uplifts, Chaco and Mogollon slopes (Kelley, 1957,

146 1967; McLellan et al., 1983a; Chamberlin \& Anderson, 1989; Craigg, 2001; Molenaar et al.,

147 2002). This terrestrial unit is typically exposed at surface near to Atarque (abandoned), Fence

148 Lake, and Quemado, New Mexico, with thickness ranging from 4.75 - $261.5 \mathrm{~m}$ (Campbell,

149 1981; Anderson, 1982a; Anderson, 1982b, 1983; Campbell, 1984; Campbell and Roybal, 1984;

150 Campbell, 1987; Hoffman, 1994). The Moreno Hill Formation, characterized by thickly bedded

151 muds and associated channel sandstones, was originally named for deposits on the slopes of Zuni

152 Plateau and Santa Rita Mesa (north of Zuni Salt Lake) (McLellan et al., 1983a and references

153 therein). In section, the lower Moreno Hill overlies the shoreface deposits of the Atarque

154 Sandstone (Formation) and the off-shore mudrocks of the Rio Salado Tongue of the lower

155 Mancos Shale (Fig. 2) (Hook, Molenaar \& Cobban, 1983; McLellan et al., 1983a; Molenaar et

156 al., 2002). The Moreno Hill is regionally overlain by a temporal unconformity (Cenozoic

157 sediments and volcanics) and is down-cut by the Eocene Baca and Miocene Fence Lake

158 Formations (locally variable) (McLellan et al., 1982; Roybal, 1982; McLellan et al., 1983a;

159 Campbell, 1984; Campbell \& Roybal, 1984; Cook \& Arkell, 1987; Campbell, 1989). Based on

160 current mapping, the three unnamed members (lower, middle, and upper) of the Moreno Hill 
161 constitute a clastic wedge (Anderson, 1981; Roybal, 1982; McLellan et al., 1983a; Campbell,

162 1984; Campbell \& Roybal, 1984; McLellan, Landis \& Biewick, 1984; Landis, 1985; Cook \&

163 Arkell, 1987; Campbell, 1989). The first formal lithostratigraphic identification of the Moreno

164 Hill Formation was by McLellan et al. (1983a), with subsequent revisions by Campbell (1984);

165 McLellan, Landis \& Biewick (1984) and Hoffman (1996), which provided further

166 sedimentological context for the Moreno Hill including depo-center characterization and

167 paleoclimatic proxies (humidity levels). Most research has focused on regional correlation and

168 economic potential of three key coal seams, the lower Antelope, the medial Cerro Prieto, and the

169 upper Rabbit, all within the lower Moreno Hill (Anderson, 1982a; Anderson, 1982b, 1983;

170 McLellan et al., 1983a; Campbell, 1984; Campbell \& Roybal, 1984; Cook \& Arkell, 1987;

171 Hoffman, 1994, 1996). Current biostratigraphic age control for the Atarque Sandstone is based

172 on the local occurrence of the range zones of Collignoniceras woollgari and Mammities

173 nodosoides. The maximum age is bounded by the middle Turonian ammonites Collignoniceras

174 woollgari woollgari and Mammities nodosoides and bivalve Mytiloides mytiloides within the

175 underlying Rio Salado Tongue of the Mancos Shale (Cobban, 1983) and by the co-occurrence of

176 Collignoniceras woollgari woollgari with Mytiloides labiatus (Wolfe \& Kirkland, 1998, p. 304)

177 or Mytiloides mytiloides (Kirkland, Smith \& Wolfe, 2005, p. 89) in the Atarque Sandstone. The

178 D-Cross (Pescado) Tongue and Gallup Sandstone (correlative to the lower member of the

179 Moreno Hill Formation) in the Pescado Creek, upper Nutria and Gallup areas contain the oysters

180 Cameleolopha lugubris and C. bellaplicata as do the lower Juana Lopez beds of the D-Cross

181 tongue at Bull Gap; radiometrically dated bentonite beds within these zones indicate an age of

18290 Ma (Wolfe \& Kirkland, 1998; Molenaar et al., 2002; Hook \& Cobban, 2011, Hook, 2012;

183 Hook \& Cobban, 2013). Regional correlations for the Moreno Hill have also been assessed via 
184 sequence- and lithostratigraphic linkages to the north-eastern Zuni Basin, with emplacement of

185 sediment roughly during the regional R-1 phase of the Greenhorn Cycle and during the New

186 Mexico-specific T-2 - R-2 Carlile Cycle (early Niobrara Cyclothem equivalent) (Hook, 1983;

187 Molenaar, 1983a, 1983b; Wolfe, 1989; Wolfe \& Kirkland, 1998; Kauffman et al., 1993;

188 Molenaar et al., 2002; Hook, 2010; Hook \& Cobban 2011).

$189 \quad$ Methods

190 All Moreno Hill samples were collected from the eastern slopes of Santa Rita Mesa at

191 Cox Ranch, located north of Quemado (Salt Lake Coal Field), west-central New Mexico (BLM

192 Permit NM17-02S). Three key stratigraphic zones were selected based on stratigraphic position

193 or proximity to known fossil horizons (Fig. 2). Specifically, bulk samples were collected from

194 the contact with the underlying Atarque (basal Moreno Hill (Cox 2), along with the middle

195 (COX 3) and uppermost (COX 4) bedded sandstone strata of the Moreno Hill Formation. A

196 fourth sample was collected near Zuni Salt Lake from the underlying Dakota Sandstone and is

197 also presented herein (whilst Carpenter [2014] notes that "Naturita Sandstone" is a more apt

198 name for this unit on the Colorado Plateau we prefer "Dakota Sandstone" to facilitate reference

199 to previous research). All samples collected were fresh and unweathered; at least 0.5 to $1.0 \mathrm{~m}$ of

200 the exterior surface of the rock was removed from the outcrop face before collecting due to

201 surficial weathering. Two gallon-sized bags of sandstone were collected at each site (Dakota

202 Sandstone, Cox 2, 3, and 4) and processed accordingly to the techniques set forth by the Central

203 Analytical Facility at Stellenbosch University including crushing, milling, panning, Frantz

204 magnetic separation, and density liquid separation. Thereafter, analysis of the recovered zircon

205 grains was undertaken via standard methods of Boise State University's Isotope Geology

Peer] reviewing PDF | (2020:10:54107:1:1:NEW 11 Jan 2021) 
206 Laboratory (Boise, Idaho, USA) as noted in several other studies (Bold, 2016; MacNaughton et

207 al., 2016; Nomore et al., 2018; Tucker et al., 2020).

208 LA-ICP-MS Methods. Zircon grains were annealed at $900^{\circ} \mathrm{C}$ for 60 hours in a muffle

209 furnace, and randomly selected grains were mounted in epoxy and polished until their centers

210 were exposed (Fig. 3). Cathodoluminescence (CL) images were obtained with a JEOL JSM-300

211 scanning electron microscope and Gatan MiniCL. Zircons were analyzed by Laser Ablation-

212 Inductively Coupled Plasma-Mass Spectrometry (LA-ICP-MS) using a ThermoElectron X-Series

213 II quadrupole ICPMS and New Wave Research UP-213 Nd:YAG UV (213 nm) laser ablation

214 system. In-house analytical protocols, standard materials, and data reduction software were used

215 for acquisition and calibration of $\mathrm{U}-\mathrm{Pb}$ dates and a suite of high field strength elements (HFSE)

216 and rare earth elements (REE). Zircons were ablated with a laser spot of $25 \mu \mathrm{m}$ wide using

217 fluence and pulse rates of $5 \mathrm{~J} / \mathrm{cm}^{2}$ and $5 \mathrm{~Hz}$, respectively, during a 45-second analysis (15-sec

218 gas blank, 30-sec ablation) that excavated a pit $\sim 15 \mu \mathrm{m}$ deep. Ablated material was carried by a

$2191.2 \mathrm{~L} / \mathrm{min}$ He gas stream to the nebulizer flow of the plasma. Quadrupole dwell times were $5 \mathrm{~ms}$

220 for $\mathrm{Si}$ and $\mathrm{Zr}, 200 \mathrm{~ms}$ for ${ }^{49} \mathrm{Ti}$ and ${ }^{207} \mathrm{~Pb}, 80 \mathrm{~ms}$ for ${ }^{206} \mathrm{~Pb}, 40 \mathrm{~ms}$ for ${ }^{202} \mathrm{Hg},{ }^{204} \mathrm{~Pb},{ }^{208} \mathrm{~Pb},{ }^{232} \mathrm{Th}$, and

$221{ }^{238} \mathrm{U}$ and $10 \mathrm{~ms}$ for all other HFSE and REE; total sweep duration is $950 \mathrm{~ms}$. Background count

222 rates for each analyte were obtained prior to each spot analysis and subtracted from the raw

223 count rate for each analyte. For concentration calculations, background-subtracted count rates for

224 each analyte were internally normalized to ${ }^{29} \mathrm{Si}$ and calibrated with respect to NIST SRM-610

225 and -612 glasses as the primary standards. Ablations pits that appear to have intersected glass or

226 mineral inclusions were identified based on Ti and P signal excursions, and associated sweeps

227 were discarded. $\mathrm{U}-\mathrm{Pb}$ dates from these analyses are considered valid if the $\mathrm{U}-\mathrm{Pb}$ ratios appear to

228 have been unaffected by the inclusions. Signals at mass 204 were normally indistinguishable 
229 from zero following subtraction of mercury backgrounds measured during the gas blank $(<1000$

$230 \mathrm{cps}{ }^{202} \mathrm{Hg}$ ), and thus dates are reported without common $\mathrm{Pb}$ correction. Rare analyses that appear

231 contaminated by common $\mathrm{Pb}$ were rejected based on mass 204 greater than baseline.

232 Temperature was calculated from the Ti-in-zircon thermometer (Watson, Wark \& Thomas,

233 2006). Because there are no constraints on the activity of $\mathrm{TiO}_{2}$, an average value in crustal rocks

234 of 0.8 was used.

235 Data were collected in three experiments in July 2020 . For U-Pb and ${ }^{207} \mathrm{~Pb} / 206 \mathrm{~Pb}$ dates,

236 instrumental fractionation of the background-subtracted ratios was corrected and dates were

237 calibrated with respect to interspersed measurements of zircon standards and reference materials.

238 The primary standard Plešovice zircon (Sláma et al., 2008) was used to monitor time-dependent

239 instrumental fractionation based on two analyses for every 10 analyses of unknown zircons.

240 Radiogenic isotope ratio and age error propagation for all analyses include uncertainty

241 contributions from counting statistics and background subtraction. The standard calibration

242 uncertainty for $\mathrm{U} / \mathrm{Pb}$ is the local standard deviation of the polynomial fit to the fractionation

243 factor of Plešovice versus time and for ${ }^{207} \mathrm{~Pb} /{ }^{206} \mathrm{~Pb}$ is the standard error of the mean of the

244 fractionation factor of Plešovice. These uncertainties are $0.6-1.0 \%(2 \mathrm{~s})$ for ${ }^{206} \mathrm{~Pb} /{ }^{238} \mathrm{U}$ and $0.2-$

$2450.4 \%$ (2s) for ${ }^{207} \mathrm{~Pb} / 206 \mathrm{~Pb}$. Age interpretations are based on ${ }^{207} \mathrm{~Pb} / 206 \mathrm{~Pb}$ dates for analyses with

$246{ }^{207} \mathrm{~Pb} /{ }^{206} \mathrm{~Pb}$ and ${ }^{206} \mathrm{~Pb} / 238 \mathrm{U}$ dates $>1000 \mathrm{Ma}$. Otherwise, interpretations are based on ${ }^{206} \mathrm{~Pb} / 238 \mathrm{U}$

247 dates. Analyses with ${ }^{206} \mathrm{~Pb} / 238 \mathrm{U}$ dates $>1000 \mathrm{Ma}$ and $>10 \%$ positive discordance or $>5 \%$

248 negative discordance are not considered. Errors on the dates are given at 2 sigma.

249 CA-TIMS U-Pb Geochronology Methods. U-Pb dates were obtained by the Chemical

250 Abrasion Isotope Dilution Thermal Ionization Mass Spectrometry (CA-TIMS) method from

251 analyses composed of single zircon grains (Table 1), modified after Mattinson (2005). Zircon 
252 was removed from the epoxy mounts for dating based on CL images and LA-ICP-MS dates. In

253 two samples, grains that yielded the five youngest LA-ICP-MS dates from an initial round were

254 analyzed in a second round. Dates from both rounds agreed in most cases. Grains were selected

255 for CA-TIMS from this population. For a third sample, the grains were too small to permit a

256 second round of analysis.

257 Zircon was put into $3 \mathrm{ml}$ Teflon PFA beakers and loaded into $300 \mathrm{ml}$ Teflon PFA

258 microcapsules. Fifteen microcapsules were placed in a large-capacity Parr vessel and the zircon

259 partially dissolved in $120 \mathrm{ml}$ of $29 \mathrm{M} \mathrm{HF}$ for 12 hours at $190^{\circ} \mathrm{C}$. Zircon was returned to $3 \mathrm{ml}$

260 Teflon PFA beakers, HF was removed, and zircon was immersed in $3.5 \mathrm{M} \mathrm{HNO}_{3}$, ultrasonically

261 cleaned for an hour, and fluxed on a hotplate at $80^{\circ} \mathrm{C}$ for an hour. The $\mathrm{HNO}_{3}$ was removed and

262 zircon was rinsed twice in ultrapure $\mathrm{H}_{2} \mathrm{O}$ before being reloaded into the $300 \mathrm{ml}$ Teflon PFA

263 microcapsules (rinsed and fluxed in $6 \mathrm{M} \mathrm{HCl}$ during sonication and washing of the zircon) and

264 spiked with the EARTHTIME mixed ${ }^{233} \mathrm{U}^{235} \mathrm{U}^{202} \mathrm{~Pb}-{ }^{205} \mathrm{~Pb}$ tracer solution (ET2535). Zircon was

265 dissolved in Parr vessels in $120 \mathrm{ml}$ of $29 \mathrm{M} \mathrm{HF}$ with a trace of $3.5 \mathrm{M} \mathrm{HNO}_{3}$ at $220^{\circ} \mathrm{C}$ for 48

266 hours, dried to fluorides, and re-dissolved in $6 \mathrm{M} \mathrm{HCl}$ at $180^{\circ} \mathrm{C}$ overnight. $\mathrm{U}$ and $\mathrm{Pb}$ were

267 separated from the zircon matrix using an HCl-based anion-exchange chromatographic

268 procedure (Krogh, 1973), eluted together and dried with $2 \mu 1$ of $0.05 \mathrm{~N} \mathrm{H}_{3} \mathrm{PO}_{4}$.

$269 \mathrm{~Pb}$ and $\mathrm{U}$ were loaded on a single outgassed Re filament in $5 \mu \mathrm{l}$ of a silica-gel/phosphoric

270 acid mixture (Gerstenberger \& Haase, 1997), and $\mathrm{U}$ and $\mathrm{Pb}$ isotopic measurements made on a

271 GV Isoprobe-T multicollector thermal ionization mass spectrometer equipped with an ion-

272 counting Daly detector. Pb isotopes were measured by peak-jumping all isotopes on the Daly

273 detector for 160 cycles and corrected for mass fractionation using the known ${ }^{202} \mathrm{~Pb} /{ }^{205} \mathrm{~Pb}$ ratio of

274 the ET2535 tracer solution. Transitory isobaric interferences due to high-molecular-weight 
275 organics, particularly on ${ }^{204} \mathrm{~Pb}$ and ${ }^{207} \mathrm{~Pb}$, disappeared within approximately 30 cycles, while

276 ionization efficiency averaged $10^{4} \mathrm{cps} / \mathrm{pg}$ of each $\mathrm{Pb}$ isotope. Linearity (to $\geq 1.4 \times 10^{6} \mathrm{cps}$ ) and

277 the associated deadtime correction of the Daly detector were determined by analysis of NBS982.

278 Uranium was analyzed as $\mathrm{UO}_{2}{ }^{+}$ions in static Faraday mode on $10^{12} \mathrm{ohm}$ resistors for 300 cycles,

279 and corrected for isobaric interference of ${ }^{233} \mathrm{U}^{18} \mathrm{O}^{16} \mathrm{O}$ on ${ }^{235} \mathrm{U}^{16} \mathrm{O}^{16} \mathrm{O}$ with an ${ }^{18} \mathrm{O} /{ }^{16} \mathrm{O}$ of 0.00206 .

280 Ionization efficiency averaged $20 \mathrm{mV} / \mathrm{ng}$ of each $\mathrm{U}$ isotope. $\mathrm{U}$ mass fractionation was corrected

281 using the known ${ }^{233} \mathrm{U} /{ }^{235} \mathrm{U}$ ratio of the ET2535 tracer solution.

282 U-Pb dates and uncertainties were calculated using the algorithms of Schmitz and Schoene

283 (2007), calibration of ET2535 tracer solution (Condon et al., 2015) of ${ }^{235} \mathrm{U} /{ }^{205} \mathrm{~Pb}=100.233$,

$284{ }^{233} \mathrm{U} /{ }^{235} \mathrm{U}=0.99506,{ }^{205} \mathrm{~Pb} / 204 \mathrm{~Pb}=8474$, and ${ }^{202} \mathrm{~Pb} / 205 \mathrm{~Pb}=0.99924, \mathrm{U}$ decay constants

285 recommended by Jaffey et al. (1971), and ${ }^{238} \mathrm{U} /{ }^{235} \mathrm{U}$ of 137.818 (Hiess et al., 2012). The

$286{ }^{206} \mathrm{~Pb} /{ }^{238} \mathrm{U}$ ratios and dates were corrected for initial ${ }^{230} \mathrm{Th}$ disequilibrium using $\mathrm{D}_{\mathrm{Th} / \mathrm{U}}=0.2 \pm 0.1$

287 (2 sigma) and the algorithms of Crowley, Schoene \& Bowring (2007), resulting in an increase in 288 the ${ }^{206} \mathrm{~Pb} / 238 \mathrm{U}$ dates of $\sim 0.09 \mathrm{Ma}$. All common $\mathrm{Pb}$ in analyses was attributed to laboratory blank 289 and subtracted based on the measured laboratory $\mathrm{Pb}$ isotopic composition and associated 290 uncertainty. U blanks are estimated at $0.013 \mathrm{pg}$.

291 A weighted mean ${ }^{206} \mathrm{~Pb} /{ }^{238} \mathrm{U}$ date is calculated from equivalent dates (probability of fit $>$ 292 0.05) using Isoplot 3.0 (Ludwig, 2003). The error is given as $\pm \mathrm{x} / \mathrm{y} / \mathrm{z}$, where $\mathrm{x}$ is the internal 293 error based on analytical uncertainties only, including counting statistics, subtraction of tracer 294 solution, and blank and initial common $\mathrm{Pb}$ subtraction, y includes the tracer calibration 295 uncertainty propagated in quadrature, and $\mathrm{z}$ includes the ${ }^{238} \mathrm{U}$ decay constant uncertainty 296 propagated in quadrature. Internal error should be considered when comparing our date with $297{ }^{206} \mathrm{~Pb} /{ }^{238} \mathrm{U}$ dates from other laboratories that used the same tracer solution or a tracer solution that 
298

299

300

301

302

303

304

305

306

307

308

309

310

311

312

313

314

315

316

317

318

319

320

was cross-calibrated using EARTHTIME gravimetric standards. Error including the uncertainty in the tracer calibration should be considered when comparing our date with those derived from other geochronological methods using the U-Pb decay scheme (e.g., laser ablation ICPMS).

Error including uncertainties in the tracer calibration and ${ }^{238} \mathrm{U}$ decay constant (Jaffey et al., 1971) should be considered when comparing our date with those derived from other decay schemes (e.g., $\left.{ }^{40} \mathrm{Ar} /{ }^{39} \mathrm{Ar},{ }^{187} \mathrm{Re}-{ }^{187} \mathrm{Os}\right)$. Errors are at 2 sigma.

\section{Results}

CA-TIMS. Results from CA-TIMS dating are used to establish MDAs for the Moreno Hill Formation (Table 1). Two grains from the lower Moreno Hill Formation (Cox 2) yield CATIMS dates of $91.275 \pm 0.048$ and $90.855 \pm 0.040 \mathrm{Ma}$, indicating that deposition occurred after 90.9 Ma. Two grains from the middle Moreno Hill Formation (Cox 3) yield dates of $99.095 \pm$ 0.051 and $91.454 \pm 0.043 \mathrm{Ma}$. These dates are older than the MDA from the underlying sample, and thus the grains are not close in age to sedimentation. For the upper Moreno Hill Formation (Cox 4) two grains were analyzed by CA-TIMS. One yields a date of $94.338 \pm 0.142 \mathrm{Ma}$ that is older than the MDA from the underlying lower Moreno Hill Formation, and thus the grain is not close in age to sedimentation. The other was broken into two fragments that were analyzed separately and yield equivalent dates of $88.648 \pm 0.074$ and $88.401 \pm 0.286 \mathrm{Ma}$, with a weighted mean of $88.632 \pm 0.072 / 0.084 / 0.127 \mathrm{Ma}(\mathrm{MSWD}=2.8$, probability of fit $=0.09)($ Table 1$)$. This is taken as the MDA, indicating deposition was after 88.6 Ma. Based on the assumption that the MDAs from the lower and upper Moreno Hill Formation are close in age to deposition, the formation is interpreted as being deposited between the Late Turonian and earliest Coniacian. LA-ICP-MS. The four samples (Dakota Sandstone and lower, middle, and upper Moreno Hill Formation) contained a broad spectrum of detrital zircon. Individual grains range from well- 
321 faceted euhedral, to somewhat rounded or minorly cracked, to fractured, rounded, or fragmented.

322 All of the grains (save for a minor few) have oscillatory and sector zoning indicative of igneous

323 growth (Fig. 3). Many grains have distinct cores. Zircons in the Dakota Sandstone are more

324 commonly round, indicative of transport, compared with the well-faceted zircon that is common

325 in the lower to middle Moreno Hill. Based on the recent work of Coutts, Matthews \& Hubbard

326 (2019), Herriott et al. (2019), and Beveridge, Roberts \& Titus (2020), our study also ran an

327 additional filter based on Tucker et al. $(2013,2016,2020)$, which omits analyses with a greater

328 than $5 \%$ (at $2 \sigma$ analytical uncertainty) discordance based on the ${ }^{207} \mathrm{~Pb} /{ }^{235} \mathrm{U}$ and ${ }^{206} \mathrm{~Pb} / 238 \mathrm{U}$ ratios.

329 The 5\% filter is more rigorous than Tucker et al. $(2013,2016)$, which utilized $10-15 \%$, based on

330 the recent results by Beveridge, Roberts \& Titus (2020). For LA-ICPMS-based MDAs, we

331 utilized the following five analyses for sample sets ranging from 30 to 100 grains: YDZ ( $n=6)$

332 (Youngest Detrital Zircon); YC2 $\sigma(n=6)$ (Youngest Cluster of grains with overlapping $2 \sigma$

333 uncertainty); Weighted Average $(n=6)$; and TuffZirc $(n=6)$; with the new addition of YSP $(n>$

334 6) (Youngest Statistical Population) (Ludwig, 2003; Coutts, Matthews \& Hubbard, 2019;

335 Herriott et al., 2019). Results are described herein and depicted in Fig. 4.

336 Dakota Sandstone. In agreement with Pike (1947), Wolfe (1989) and more recently

337 Carpenter (2014), and based on regional characterization of the trough-bedded alluvial

338 sandstone, this sample was recovered from the laterally extensive lower "Dakota alluvial unit" or

339 "main body of the Dakota Sandstone" (McLellan et al., 1983b). We do not, however, recognize

340 the "Cliff Dwellers Sandstone" nomenclature for this unit (Wolfe, 1989). The Dakota Sandstone

341 has the widest spectrum of dates and grain morphologies. Of the 97 grains ablated ( 86 included),

34231 are Precambrian, four are Paleozoic, and 51 grains are Mesozoic. These youngest date

343 signatures are $\mathrm{YDZ}$ at $96.13+1.6 /-2.0 \mathrm{Ma}$, Weighted Average at $96.5 \pm 1.6 \mathrm{Ma}, \mathrm{YC} 2 \sigma$ at $96.5 \pm$ 
344 2.5 Ma (MSWD = 1.2), TuffZirc date at 96.3 +3.2/-1.8 Ma, and YSP 95.2 $\pm 0 \mathrm{Ma}(\mathrm{MSWD}=$

345 0.96) (Fig. 4, Table 2). The mean of the youngest date signatures is 96.1 Ma (Table 2; Online

346 Supplementary Table 1). Based on this date we suspect that this lower "Dakota sandstone" is

347 equivalent to the basal Naturita Sandstone in Southern Utah (Barclay et al., 2015; Laurin et al., 348 2019; Tucker et al., 2020).

349 Lower Moreno Hill Formation. Of the 101 grains ablated ( 88 included), 60 are

350 Precambrian, Paleozoic grains are absent, and 28 are Mesozoic. The youngest date signatures 351 are YDZ at 91.16+2.5/-2.1 Ma, Weighted Average at 91.4 + 2.9 Ma, YC2 $\sigma$ at 90.2 $\pm 2.5 \mathrm{Ma}$,

352 TuffZirc date at 91.7 +3.0/-2.4 Ma, YSP at 90.2 $\pm 1.2 \mathrm{Ma}(\mathrm{MSWD}=1.19)$ (Fig. 4, Table 2). The 353 mean of the youngest date signatures is 90.9 Ma (Table 2; Online Supplementary Table 1).

354 Middle Moreno Hill Formation. Of the 99 grains ablated (94 included), 57 are

355 Precambrian; Paleozoic grains are absent, and 37 grains are Mesozoic. The youngest grain

356 signatures are YDZ at 89.5+3.4/-2.4 Ma, Weighted Average at 90.2 $\pm 3.7 \mathrm{Ma}, \mathrm{YC} 2 \sigma$ at $89.1 \pm$

357 2.2 Ma, TuffZirc date at 89.4 +1.5/-1.8 Ma, YSP at 88.67 $\pm 1.1 \mathrm{Ma}(\mathrm{MSWD}=1.38)$ (Fig. 4,

358 Table 2). The mean of the youngest date signatures is $89.3 \mathrm{Ma}$ (Table 2; Online Supplementary

359 Table 1).

360

Upper Moreno Hill Formation. Of the 24 grains ablated (16 included), three grains are

361 Precambrian, one is Paleozoic, and 12 are Mesozoic. The youngest date signatures are YDZ at

$36289.3+3.4 /-2.4 \mathrm{Ma}$, Weighted Average at 90.5 $\pm 4.9 \mathrm{Ma}$, YC2 $\sigma$ at $90.5 \pm 3.3 \mathrm{Ma}$, TuffZirc date at

$36389.0+1.7 /-1.8 \mathrm{Ma}$, and YSP at 88.82 $\pm 1.7 \mathrm{Ma}(\mathrm{MSWD}=0.94)($ Fig. 4, Table 2). The mean of

364 the youngest date signatures is 89.6 Ma (Table 2; Online Supplementary Table 1).

365 Detrital Populations: Precambrian \& Phanerozoic-Paleozoic. This study builds upon

366 well-documented tectonic reconstructions and source terranes (Fig. 5) (Willis, 1999; Dickinson 
367 \& Gehrels, 2003; DeCelles, 2004; Dickinson and Gehrels, 2008; Dickinson \& Gehrels, 2009a;

368 Dickinson \& Gehrels, 2009b; Lawton \& Bradford, 2011; Laskowski, DeCelles \& Gehrels, 2013),

369 which allow for reliable linkages. The Dakota Sandstone sample displays a diverse assemblage

370 of grain ages and populations. In contrast, zircons from the Moreno Hill Formation are either

371 Precambrian $\mathrm{n}>1.0 \mathrm{Ga}$ or Mesozoic $(\mathrm{n}<251 \mathrm{Ma})$. All samples contain individual grains or

372 minor populations that are $>2.0 \mathrm{Ga}$ and are likely reworked continental fragments (Gehrels et

373 al., 1995; Linde et al., 2016; Tucker et al., 2020). Large populations of grains between 1.9 and

$3741.5 \mathrm{Ga}$ were identified in all samples. As a result of multi-phased sedimentary recycling, these

375 detrital zircons can be meaningfully associated with 1) the Trans-Hudson and Wopmay

376 orogenies $(2.0-1.5 \mathrm{Ga}) ; 2)$ the Yavapai/Mazatzal terranes, and; 3$)$ the Grenville terrane (1.7-1.0

377 Ga) (Gehrels et al., 1995; Van Schmus, Bickford \& Turek, 1996; Whitmeyer \& Karistorm,

378 2007). Due to the distance of the Sevier (west) and Maria (south-southwest) Fold and Thrust

379 Belts, grains between 1.7 and 1.2 Ga are likely from uplifted basement (Yavapai/Mazatzal).

380 Therefore this study is in agreement with regional studies that the most likely source terrane for

381 the above-mentioned grains is the Mogollon Highlands (Barth et al., 2004; Dickinson \& Gehrels,

382 2008; Salem, 2009; Lawton \& Bradford, 2011; Laskowski, DeCelles \& Gehrels, 2013; Szwarc et

383 al., 2015). Our study also recognized the possibility, though less likely, that source terranes

384 include but are not limited to 1) Antarctica; 2) Australia; 3) Africa; or even yet to be identified

385 proto-Rodinian terranes (Gehrels \& Stewart, 1998; Laskowski, DeCelles \& Gehrels, 2013; Linde

386 et al., 2016). Of the four samples included in this study, only the Dakota Sandstone contains a

387 population of Paleozoic grains $(n=4)$. This may reflect a bias in sampling or more likely that

388 sources such as the Amarillo-Wichita to Appalachian Orogeny as noted by Laskowski, DeCelles 
$389 \&$ Gehrels (2013) did not contribute much into this area. In any event, dates from this period in

390 North America's tectonic history are distinctly absent within the Moreno Hill Formation (Fig. 5).

391 Detrital Populations: Phanerozoic-Mesozoic. We describe the Mesozoic detrital zircon

392 populations from the Dakota Sandstone and the overlying Moreno Hill Formation separately. For

393 both, we describe the youngest populations in accordance with DeCelles (2004): Phases A (160-

$394140 \mathrm{Ma}$ ); B (140-105 Ma) and C (105-80 Ma) (Fig. 6) (DeCelles \& Graham, 2015). In the

395 Dakota Sandstone, the majority of dates are Triassic $(n=24)$ and Jurassic $(n=20)$ with the

396 remaining few $(n=9)$ being Cretaceous. Specific Triassic - Jurassic sediment source terranes,

397 which rely on well-understood southern Cordilleran orogenic systems that were active between

398260 and 145 Ma include the 1) East Mexico Arc; 2) Mojave Desert, and; 3) Wallowa/Olds Ferry

399 terranes; along with early phases of the 4) Western Coast Plutonic Complex; 5) Sierra Nevada

400 Batholith; and 6) Omineca Belt (Gehrels \& Stewart, 1998; Gehrels et al., 2009; LaMaskin et al.,

401 2011; Gehrels \& Pecha, 2014; Gaschnig et al., 2017; Quinn et al., 2018). All of these grain

402 populations can also be linked to heavily-reworked multi-generational recycling of sedimentary

403 blankets lying east of the Sevier Highlands and north of the Mogollon Highlands, potentially

404 including proximal units underlying the sub-Dakota Sandstone angular unconformity (Wolfe,

405 1989; Molenaar et al., 2002; Dickinson \& Gehrels, 2003; Lawton et al., 2003; DeCelles, 2004;

406 Dickinson \& Gehrels, 2009a; Dickinson \& Gehrels, 2009b; Laskowski, DeCelles \& Gehrels, 407 2013; Gehrels \& Pecha, 2014).

408 Other than the notable Precambrian signatures, all four samples contain distinct late

409 Jurassic - Cretaceous multi-grain populations with the majority within phases A (160 - $140 \mathrm{Ma})$

410 and B (140 - $105 \mathrm{Ma})$ and the most youthful populations falling within Phase C (105 - $80 \mathrm{Ma})$

411 (DeCelles \& Graham, 2015). All samples assessed in this study contain multi-grain populations 
412 within Phase C, which we link to the westerly lying Cordilleran Arc; more specifically, the

413 southern portion of the Sierra Nevada Batholith, the northern portion of the Peninsular Ranges

414 Batholith, and minor volcanism near the Maria Fold and Thrust Belt (DeCelles, 2004; Dickinson, 415 2008; Busby, 2012; Hildebrand \& Whalen, 2012; LaMaskin, 2012; Szwarc et al., 2015; Pecha et

416 al., 2018; Lawton, 2019; DeGraaff Surpless et al., 2019). Shorter-lived and more-localized

417 volcanic events within Phases B and C that could have been contributors include the 1) Black

418 Rock Arc Terrane (114 - $103 \mathrm{Ma})$; 2) Sierra Crest Magmatic Event (98 - $86 \mathrm{Ma})$; 3) Santa Rosa

419 Range and the Bloody Run Hills (110 - $85 \mathrm{Ma})$; and 4) Soldier and Cathedral peak plutons (Fig.

420 6) (Dickinson \& Gehrels, 2008; Lawton, Hunt \& Gehrels, 2010; Hunt et al., 2011; Laskowski,

421 DeCelles \& Gehrels, 2013; Cao et al., 2015, Fig. 15, p. 316, cycles 1, 2 and early Phase 3;

422 Szwarc et al., 2015; Brown, Hart \& Stuck, 2018; Pecha et al., 2018; Tucker et al., 2020). Within 423 the southwestern portion of the Arc, possible Phase C contributors of the most youthful zircon 424 populations include the southeastern zone of the Sierra Nevada Batholith (less likely Central 425 Sierra Nevada Batholith) and the northeastern zone of the Peninsular Ranges Batholith (Fig. 6) 426 (Hildebrand \& Whalen, 2012; DeCelles \& Graham, 2015; Yonkee \& Weil, 2015). Cretaceous 427 grain populations could yet be linked to the Mogollon Highlands where Pike (1947) noted 428 sedimentary rocks (with interbedded volcanics) indicated by fossil content to be "Benton-aged" 429 near Deer Creek, Arizona.

430 Lastly, in light of recent literature documenting highly variable grain sorting and 431 emplacement histories, other much less-probable but potential sources include 1) Owhyee 432 Mountains; 2) Atlanta Lobe of the Idaho Batholith; and 3) Eastern Coast Plutonic Complex 433 (Parrish, Gaynor \& Swift, 1984; Slingerland et al., 1996; Gaschnig et al., 2010; Fricke, Foreman 
434 \& Sewall, 2010; Hay \& Floegel, 2012; Laskowski, DeCelles \& Gehrels, 2013; Finzel, 2017;

435 Sauer et al., 2017; Brown, Hart \& Stuck, 2018; Quinn et al., 2018).

436 K-S Analysis. The Kolmogorov-Smirnov test (K-S test) was applied to determine the

437 likelihood that the age profiles of sampled zircons obtained from the Dakota Sandstone and from

438 the lower, middle and upper members of the Moreno Hill are statistically similar (pass) or

439 dissimilar (fail). In this study, we utilized a Cumulative Distribution Function (CDF) via date

440 and its corresponding uncertainty with a $95 \%$ confidence interval, in that $p$-values $>0.05$ pass

441 and $<0.05$ fail the test (Fig. 7) (Dickinson \& Gehrels, 2008; Barbeau et al., 2009a; Tucker et al.,

$4422016,2020)$.

443 When comparing all four samples based on a CDF across all reported dates spanning

444 Precambrian-Proterozoic - Mesozoic-Cretaceous we note no statistical similarity between the

445 underlying Dakota Sandstone and the overlying Moreno Hill ( $p$-value $=0.00$ ). Furthermore, with

446 the same parameters, the lower and middle Moreno Hill samples have genetic similarity (p-value

$447=0.222$ ), yet neither showed similarity with the upper Moreno Hill sample ( $p$-values $=0.003$ and

448 0.001). The lack of genetic similarity between Moreno Hill samples reflects 1) the limited

449 number of recovered zircon grains from the upper Moreno Hill; 2) statistical effects of the $5 \%$

450 cutoff, and; 3) the very youthful multi-grain population between 89 and 88 Ma that is not present

451 in the lower to middle Moreno Hill. This pattern is somewhat different when the K-S test is

452 applied only to Mesozoic populations. For instance, the Dakota and the middle Moreno Hill have

453 genetic similarity ( $p$-value $=0.790$ ), yet the Dakota fails to be significantly different from all

454 other comparisons. When we compare only Moreno Hill samples, the lower and middle samples

455 present genetic similarity ( $\mathrm{p}$-value $=0.220$ ), and no similarity to the upper Moreno Hill ( $\mathrm{p}$-value

$456=0.003 / 0.001)($ Fig. 7). Such subtle variances in confidence are potentially linked to variably 
457 geographically influenced drainage systems and/or to temporally dissimilar volcanic inliers

458 within the westerly lying arc rather than to a single, enduring source (Fitz-Diaz, Hudleston \&

459 Tolson, 2011 and references therein).

460 The above described multi-faceted source terrane narrative is fairly complex; therefore,

461 we sought to confirm these observations by utilizing the methods described by Cawood,

462 Hawkesworth \& Dhuime (2012), which links cumulative proportion curves with tectonic sources

463 (Fig. 7). When results for dates between 0 and $3.5 \mathrm{Ga}$ are plotted on cumulative proportion

464 curves, all four samples variably plot between zones A (convergent), B (collisional), and C

465 (extensional) confirming the complex detrital source terrane history (Cawood, Hawkesworth \&

466 Dhuime, 2012). By and large, all youthful populations $(\mathrm{n}<100 \mathrm{Ma})$ from all four samples

467 indicate a convergent margin (westerly lying arc); yet, weak genetic similarity between youthful

468 samples indicates that these are likely derived from different volcanic inliers (Dakota and the

469 middle Moreno Hill $p$-value $=0.790$ and the lower and upper Moreno Hill $p$-value $=0.211$, with

470 all other comparisons failing the 0.05 significance threshold). It should be noted that with the 5

$471 \%$ filter, only 16 grains were approved for the upper Moreno Hill, and should be treated as a

472 proxy only. However, when all the samples are presented on a detrital zircon age probability

473 plot, irrespective of the final grain count, all samples present a Foreland Basin spectrum (in

474 agreement with Cawood, Hawkesworth \& Dhuime, 2012, Fig. 1 C and D, p. 876).

Discussion

476

This study sought to 1) refine the depositional age and duration of sedimentation of the

477 Moreno Hill Formation; 2) provide newly calibrated linkages based on the revised temporal

478 framework; and 3) determine likely source terranes. Our results demonstrate that emplacement of

479 sediment into the Moreno Hill depo-center was diachronous, occurring in two distinct phases. 
480 The first phase of sedimentation occurred after 90.9 Ma and terminated before 88.6 Ma (lower to

481 middle Moreno Hill), spanning the late Turonian to very early Coniacian (Fig. 8). The second

482 phase of sedimentation occurred shortly thereafter 88.6 Ma (upper Moreno Hill), very early

483 Coniacian (Fig. 8) (Cohen et al., 2013:v2020/03). This two-phased deposition is reflected in the

484 results of the K-S test, with only the lower and middle Moreno Hill having genetic similarity.

485 Therefore, a comparison of stratigraphic position and the resulting MDAs would strongly

486 indicate that there was no synchronicity between sedimentation and the emplacement of detrital

487 zircons in the middle Moreno Hill, rather that only the lower and upper Moreno Hill could

488 potentially be nearer to syndepositional (Rossignol et al., 2019; Tucker et al., 2020; R Renaut et

489 al., 2019 - 2020). In light of the seemingly strong temporal relationship between the lower and

490 middle members of the Moreno Hill, the current informal subdivision of the formation into its

491 three members will be reassessed in a forthcoming manuscript.

492 This study notes that based on the depositional nature of detrital zircon (Gehrels, 2014),

493 sedimentation into the Moreno Hill could have been entirely within the very early Coniacian;

494 however, key pieces of evidence seemingly corroborate staggered pulses of detrital-rich

495 sedimentation into the Moreno Hill depo-center. The first phase of sedimentation is well-

496 documented to have co-occurred with anoxic paleosols and distinct coal horizons within a distal

497 alluvial plain (Fig. 9) (McLellan et al., 1983a; Landis et al., 1985; Mack, 1992; Hoffman, 1996;

498 Sweeney et al., 2009). On the other hand, the upper Moreno Hill is distinctly different,

499 preserving paleosols generally indicative of subaerial conditions and aridification with co-

500 occurring fluvial channel belts (Roybal, 1982; Campbell, 1984; Hoffman, 1996). While the

501 complete lithological review of the Moreno Hill is the focus of a forthcoming manuscript, we

502 wish to highlight the above-mentioned differences between the lower and upper Moreno Hill are 
503 supported by our own observations. The lower Moreno Hill is characterized by thickly

504 interbedded dark fissile to blocky plant hash-rich mudrocks with associated coal seams, finely

505 laminated siltstones, fine to medium-grained laterally discontinuous sandstones, and fine to

506 coarsely-grained sublitharenitic to arkosic laterally continuous multi-story planar and distinctly

507 trough-cross-bedded ledge-forming sandstones more prevalent towards the upper parts of the

508 member; whereas, the upper Moreno Hill is characterized by lighter-colored more fissile

509 mudrocks, siltstones and lesser-occurring very finely to medium-grained subarkosic lenticular

510 trough-cross-bedded sandstones (details in forthcoming manuscript). Beyond local

511 sedimentological differences, regional linkages can be utilized to corroborate this study's

512 interpretation of diachronous sedimentation. Based on regional biostratigraphic linkages of $C$.

513 woollgari woollgari and either M. labiatus (Wolfe \& Kirkland [1998, p. 304] or M. mytiloides

514 (Kirkland, Smith \& Wolfe [2005, p. 89]), the underlying diachronous Atarque Sandstone was

515 emplaced during the latest early-Turonian to early-middle Turonian $(\sim 93.4$ and $\sim 92.5 \mathrm{Ma})$

516 (Kauffman et al., 1993; Cobban et al., 2006). Biostratigraphically controlled radiometric

$517{ }^{40} \mathrm{Ar} /{ }^{39} \mathrm{Ar}$ (sanidine) dates correlative with the lower Moreno Hill Formation are available from

518 other diachronous units including the Ferron Sandstone, Utah, and from the Juana Lopez

519 Member of the Mancos Shale in San Juan County, New Mexico (Obradovich, 1993; Cobban et

520 al., 2006). Both dates have been re-calibrated to current standards, dating the bentonite beds

521 within the $P$. hyatti and $P$. macombi Zones to $91.1 \pm 0.5 \mathrm{Ma}$ and $90.8 \mathrm{Ma} \pm 0.7$, respectively

522 (Fowler, 2017). A bentonite from within the S. preventricosus Ammonite Zone (Lower

523 Coniacian), Marias River Shale in Montana, was dated and recalibrated to $88.9 \pm 0.6 \mathrm{Ma}$, thus

524 constraining the age of Flemingostrea elegans within the Mulatto Tongue of the Mancos Shale

525 (which overlies the upper member-correlative Dilco Coal Member of the Crevasse Canyon 
526 Formation) to early Coniacian (Obradovich 1993; Molenaar et al., 2002; Hook, 2010; Fowler, 527 2017).

528 Our MDA for the lower Moreno Hill corroborates this placement (within \pm 1 Ma) with 529 the initial sedimentation into Moreno Hill depo-center occurring after 90.9 Ma (in agreement 530 with Wolfe, 1989; Obradovich, 1993; Dyman et al., 1994; Wolfe \& Kirkland, 1998, Cobban et 531 al., 2006; Molenaar et al., 2002; Meyers et al., 2012). Furthermore, the emplacement of 532 sediment into the upper Moreno Hill depo-center is slightly younger than the original estimates 533 by Wolfe and Kirkland (1998) of the upper Turonian. This study interprets that sedimentation 534 occurred after 88.6 Ma, the very early Coniacian (Cohen et al., 2013:v2020/03), in agreement 535 with the supposition of Chin et al. (2019). Accordingly, based on our MDA, the basal upper 536 Moreno Hill could yet be linked to the S. preventricosus (88.9 Ma) or S. ventricosus (88.8 Ma) 537 Ammonite Zones (Ogg and Hinov, 2012; Fowler, 2017). Therefore, the sedimentation processes 538 of the upper Moreno Hill may have had more direct linkages with the Gallup Sandstone and 539 Crevasse Canyon Formation than previously thought (McLellan et al., 1983a; Molenaar et al., 540 2002).

541 In light of the above interpretations and if it assumed the most recent revision of the 542 Gallup Delta by Lin and Bhattacharya (2019) and Lin, Bhattacharya \& Stockford (2019) is 543 accurate, the Moreno Hill depo-center was likely a sedimentary conduit for the Gallup Delta.

544 Seminal work by Lin, Bhattacharya \& Stockford (2019) indicates that initial sedimentation in the 545 Gallup System occurred near \pm 89.6 Ma for the Lower Gallup and terminated by \pm 88.4 Ma for 546 the Upper Gallup (Lin, Bhattacharya \& Stockford, 2019, Fig 20), and geographically is placed at 547 or just north to northeast of the Moreno Hill depo-center (Lin, Bhattacharya \& Stockford, 2019, 548 Fig 2a,b). Therefore, based on this study's initial findings, we interpret the lower Moreno Hill 
549 would have formed the proximal portions of the delta plain with co-occurring channel

550 complexes, vast back swamps, and accumulations of water-saturated floodplain fines (Fig. 9).

551 By approximately $88.6 \mathrm{Ma}$ (but no older) the delta prograded further north by northeast Lin,

552 Bhattacharya \& Stockford, 2019, Fig. 20, p. 571, Sequence 5, 4, 3), which is reflected in the

553 Moreno Hill sedimentation. The once delta plain shifted to a distal floodplain with the continued

554 development of the fluvial complex and adjacent floodplain fines preserved in slightly more arid

555 climatic conditions (Roybal, 1982; Campbell, 1984; Hoffman, 1996; this study). In a broader

556 context, with the newly interpreted MDAs for the Moreno Hill, emplacement of sediment into

557 the depo-center would have initiated during the latest phase of the Greenhorn continuing through

558 the Frontier-Ferron regression (Mancos Seaway) (Kauffman, 1984, Blakey, 2014; Lowery et al.,

559 2018, Fig. 4, p. 14; Miall and Catuneanu, 2019; and references therein). The revision of

560 lithostratigraphic, sequence stratigraphic, and biostratigraphic ties are the focus of a forthcoming

561 manuscript and is beyond the scope of this particular study. However, these findings thus far are

562 in agreement with the regional framework(s) (Fig. 9) by Roberts \& Kirschbaum (1995, Fig. 10,

563 p. 23 and Fig. 13, p. 29), Pecha et al. (2018) and Lin, Bhattacharya \& Stockford (2019).

564 The oldest detrital zircons in the Moreno Hill Formation are Precambrian and are

565 interpreted as being from the uplifted and eroding Yavapai and Mazatzal blocks in the adjacent

566 Mogollon Highlands. All Moreno Hill Formation samples are void of Palaeozoic multi-grain

567 populations. Triassic to middle Jurassic recycled grains and populations are interpreted as being

568 from the Appalachian and Amarillo-Wichita uplifts (300 - $200 \mathrm{Ma})$ with younger grains being

569 from westerly lying terranes within the early phases of the Cordilleran Arc and heavily-reworked

570 multi-generational recycling of sedimentary blankets (aeolianites) lying east of the Sevier

571 Highlands and north of the Mogollon Highlands (Dickinson \& Gehrels, 2003; Lawton et al., 
572 2003; DeCelles, 2004; Dickinson \& Gehrels, 2009a; Dickinson \& Gehrels, 2009b; Laskowski,

573 DeCelles \& Gehrels, 2013; Gehrels \& Pecha, 2014). Late Jurassic - "mid-Cretaceous" zircon

574 populations can be linked to igneous terranes in the southwestern portion of the Cordilleran Arc,

575 specifically the western zones of the Sierra Nevada and Peninsular Ranges Batholiths

576 (Laskowski, DeCelles \& Gehrels, 2013; Tucker et al., 2020). Based on regional paleo-drainage

577 reconstructions from southwest to northeast, we conclude that the most youthful (near-

578 syndepositional) populations are most likely derived from the southeastern zone of the Sierra

579 Nevada Batholith and the northeastern zone of the Peninsular Ranges Batholith (Roberts \&

580 Kirschbaum, 1995; Hildebrand \&Whalen, 2012; Yonkee \& Weil, 2015; Pecha et al., 2018; Lin,

581 Bhattacharya \& Stockford, 2019). If the Moreno Hill is compared to the Dakota Sandstone, our

582 study confidently identifies a long-term shift in probable source terranes and is linked to an

583 evolving catchment system. Specifically, the impacts of the eastward migration of the forebulge

584 to the north (Currie, 1997; DeCelles, 2004; White, Furlong \& Arthur, 2004; DeCelles \& Coogan,

585 2006; Yonkee \& Weil, 2015; Miall \& Catuneanu, 2019) may have extended further south to

586 southwest than previously recognized, thus creating a topographic high, which diverted drainage

587 into the north (foredeep) or northeast (backbulge) (Fig. 9 B, C). We interpret that as the

588 forebulge migrated eastward, it slowly cut off westerly lying sources, including the Sevier

589 Highlands and northern Sierra Nevada Batholith (Fig. 9). Volcaniclastic to volcanilithic-rich

590 sediment that blanketed the Mogollon Highlands during eruption phases would have been eroded

591 and mixed with other Mogollon Highland sediments and transported northeast to the Moreno

592 Hill depo-center and the Gallup Delta. Temporally, the tectonic driver for sediment and resulting

593 influence on drainage (southwest to northeast) can be confidently linked to the $90-86 \mathrm{Ma}$ 
594 development of the Maria Fold and Thrust Belt (Spencer \& Reynolds, 1990; Knapp \& Heizler, 595 1990, Barth et al., 2004; Salem, 2009; Szwarc et al., 2015).

596 The Moreno Hill Formation preserves a globally unique, terrestrial vertebrate fauna that 597 has been used alongside other key formations (e.g., the Cedar Mountain Formation [Cifelli et al., 598 1997; Kirkland et al., 1997; Zanno \& Makovicky, 2013; Zanno et al., 2019], and the Cloverly 599 Formation [Zanno \& Makovicky, 2011; Farke et al., 2014]) to detangle the pace of ecological 600 restructuring in western North America during the mid-Cretaceous (Nesbitt et al., 2019). 601 Specifically, the Moreno Hill Assemblage (sensu Nesbitt et al., 2019), which currently 602 derives solely from the lower Moreno Hill Formation (Wolfe \& Kirkland, 1998), has been used 603 to pinpoint first and last appearance dates for a variety of key taxa including therizinosauroids, 604 hadrosauroids, and ceratopsians (e.g., Wolfe \& Kirkland, 1998; Kirkland \& Wolfe, 2001; 605 McDonald, Wolfe \& Kirkland, 2010; Gates et al., 2011), and fills in biodiversity data otherwise 606 only supplemented temporally by the more poorly categorized Straight Cliffs Formation 607 regionally (e.g., Titus, Roberts \& Albright, 2013; Albright \& Titus, 2016). Although Wolfe and 608 Kirkland (1998) suggest a middle - upper Turonian age for the lower Moreno Hill Formation 609 based on ammonite biostratigraphy (Molenaar et al., 2002), recent paleontological studies have 610 used an early middle Turonian age ( $92 \mathrm{Ma})$ in taxon descriptions (e.g., Nesbitt et al., 2019).

611 Our MDA of 90.9 Ma from the Moreno Hill Assemblage compares well with the temporal

612 framework of Wolfe \& Kirkland (1998) and suggests that taxon ages should be refined to be 613 approximately one million years younger than previously recognized, whereas, the limited fossils 614 recovered from the upper Moreno Hill are Coniacian. 615 
616

617

618

619

620

621

622

623

624

625

626

627

628

629

630

631

632

633

634

635

636

637

638

\section{Conclusion}

This study presents a newly calibrated chronostratigraphic framework for the Moreno

Hill Formation exposed within the Zuni Basin, New Mexico. By coupling CA-TIMS and LA-

ICP-MS data, we identify that emplacement of the most reliable youthful zircon populations

preserved within the Moreno Hill depo-center occurred in two distinct phases. The first pulse of deposition occurred after 90.9 Ma (lower Moreno Hill), and the second pulse of sediment emplacement occurred after 88.6 Ma. Based on the principle of detrital zircon, the emplacement of the Moreno Hill is diachronous, Turonian/Coniacian. Based on LA-ICP-MS data this study was able to detangle a complex history of detrital input and confidently identify likely volcanic source terranes. Youthful populations are interpreted to derive from the westerly Cordilleran Arc (Phase C), and more likely Peninsular Ranges Batholith and the southernmost to central Sierra Nevada Batholith (Fig. 9). Reworked volcanic detritus and co-occurring detrital sediment from the Maria Fold and Thrust Belt and the Mogollon Highlands were enriched with Cordilleran Arc detritus and transported via fluvial complexes to the developing Gallup Delta (Fig. 9). The Moreno Hill is interpreted to be the proximal delta plain and distal fluvial system to the Gallup Delta (Hutsky \& Fielding, 2016; Lin \& Bhattacharya, 2019; Lin, Bhattacharya \& Stockford, 2019). Our future investigations into the Moreno Hill Formation will seek to couple this newly calibrated temporal framework with that of historically significant lithostratigraphic and biostratigraphic records, which are now somewhat juxtaposed with our current results. Future work will also seek to provide a comprehensive review of the Moreno Hill sedimentary system including a stratigraphic revision of its current subdivision. Finally, these efforts present a novel temporal framework for the Moreno Hill assemblage that will allow refined comparisons with early-Late Cretaceous terrestrial ecosystems of the Western Interior Basin. 


\section{Acknowledgments}

641 We thank staff and students from the North Carolina Museum of Natural Sciences, North

642 Carolina State University and Stellenbosch University including L. Herzog; A. Moyer; A.

643 Canoville; H. Avrahami; D. Giraldo; A. Bell; A. Roychoudhury, and M. Storm for their support 644 and companionship during the 2018 expedition to the Zuni Basin. We also thank the Bureau of 645 Land Management - New Mexico and P. Gensler, M. Papirtis and the staff of the Socorro Field 646 Office for permitting support. We are especially grateful to the people of Quemado for their

647 friendliness and hospitality and to D. Wolfe for meaningful discussions about the current type 648 section for the Moreno Hill Formation and other associated outcrops. Lastly, we specially thank 649 editor Ian Moffat, reviewer Greg Ludvigson and an anonymous reviewer for their helpful 650 comments and suggestions which greatly strengthened this manuscript. 651 652 
653

654

655

656

657

658

659

660

661

662

663

664

665

666

667

668

669

670

671

672

673

674

675

\section{References}

Admakin, L.A., 2001. Lithogenetic indicators of tonsteins. Lithology and Mineral Resources, 36(1), pp.23-32. https://doi.org/10.1023/A:1004839714374

Albright III, L.B., Titus, A.L., 2016. Magnetostratigraphy of Upper Cretaceous strata in Grand Staircase-Escalante National Monument, southern Utah: The Santonian-Campanian Stage boundary, reassessment of the C33N/C33R magnetochron boundary, and implications for regional sedimentation patterns within the Sevier Foreland Basin. Cretaceous Research, 63, pp.77 - 94. https://doi.org/10.1016/j.cretres.2016.03.004

Anderson, O.J., 1981. Geology and coal resources of the Cantaralo Spring Quadrangle, Cibola County, New Mexico. New Mexico Bureau of Mines and Mineral Resources Open File Report, 142, 18p.

Anderson, O.J., 1982a. Geology and coal resources of the Twentytwo Spring 7 1/2’ Quadrangle, Catron and Cibola Counties, New Mexico. New Mexico Bureau of Mines and Mineral Resources Open File Report, 143, 8p.

Anderson, O.J., 1982b. Geology and coal resources of the Venadito Camp Quadrangle, Cibola County, New Mexico. New Mexico Bureau of Mines and Mineral Resources Open File Report, 163, 31p. 
676 Anderson, O.J., 1983. Geology and Coal Resources of the Atarque Lake Quadrangle, Cibola

677

678

679

680

681

682

683

684

685

686

687

688

689

690

691

692

693

694

695

696

697

698

County, New Mexico. New Mexico Bureau of Mines and Mineral Resources Open File Report, 167, 29p.

Barbeau Jr, D.L., Davis, J.T., Murray, K.E., Valencia, V., Gehrels, G.E., Zahid, K.M., Gombosi, D.J., 2009. Detrital-zircon geochronology of the metasedimentary rocks of north-western Graham Land. Antarctic Science, 22, pp.65- 78. https://doi.org/10.1017/S095410200999054X

Barbeau Jr, D.L., Gombosi, D.J., Zahid, K.M., Bizimis, M., Swanson-Hysell, N., Valencia, V., Gehrels, G.E., 2009. U-Pb zircon constraints on the age and provenance of the Rocas Verdes basin fill, Tierra del Fuego, Argentina. Geochemistry, Geophysics, Geosystems, 10(12), 11p. https://doi.org/10.1029/2009GC002749

Barclay, R.S., Rioux, M., Meyer, L.B., Bowring, S.A., Johnson, K.R., Miller, I.M., 2015. High precision U-Pb zircon geochronology for Cenomanian Dakota Formation floras in Utah. Cretaceous Research, 52, pp.213 - 237. https://doi.org/10.1016/j.cretres.2014.08.006

Barth, A.P., Wooden, J.L., Jacobson, C.E., Probst, K., 2004. U-Pb geochronology and geochemistry of the McCoy Mountains Formation, southeastern California: A Cretaceous retroarc foreland basin. Geological Society of America Bulletin, 116(1-2), pp.142 - 153. https://doi.org/10.1130/B25288.1

Peer] reviewing PDF | (2020:10:54107:1:1:NEW 11 Jan 2021) 
699 Benton, M.J., 2009. The Red Queen and the Court Jester: Species Diversity and the Role of

700 Biotic and Abiotic Factors Through Time. Science, 323(5915), pp.728 - 732.

$701 \quad$ https://doi.org/10.1126/science. 1157719

702

703 Beveridge, T.L., Roberts, E.M., Titus, A.L., 2020. Volcaniclastic member of the richly

704 fossiliferous Kaiparowits Formation reveals new insights for regional correlation and

705 tectonics in southern Utah during the latest Campanian. Cretaceous Research, p.104527.

706 https://doi.org/10.1016/j.cretres.2020.104527

707

708

Bilodeau, W.L., 1986. The Mesozoic Mogollon Highlands, Arizona: An Early Cretaceous Rift Shoulder. The Journal of Geology, 94(5), pp.724 - 735. https://doi.org/10.1086/629077

710

711

Blakey, R.C., 2014. Paleogeography and paleotectonics of the Western Interior Seaway, Jurassic - Cretaceous of North America. Search and Discovery, 30392, 72 p.

713

714

Bold, U., 2016. Neoproterozoic to Paleozoic Geology of Southwestern Mongolia (Ph.D Thesis). Harvard University, Harvard, 570p.

716

717 Brown, K.L., Hart, W.K., Stuck, R.J., 2018. Temporal and geochemical signatures in granitoids of northwestern Nevada: Evidence for the continuity of the Mesozoic magmatic arc through the western Great Basin. Lithosphere, 10(2), pp.327 - 350.

720 https://doi.org/10.1130/L694.1 
722 Campbell, F.W., 1981. Geology and coal resources of Cerro Prieto and the Dyke quadrangles.

723 New Mexico Bureau of Mines and Mineral Resources Open File Report, 144, 70p.

724

725 Campbell, F.W., 1984. Geology and coal resources of Cerro Prieto and the Dyke quadrangles, 726 Cibola and Catron Counties, NM. New Mexico Geology, February 1984, pp.6-10.

Campbell, F.W., 1987. Coal geology of the Salt Lake coal field. In: Roybal, G.H., Anderson, of Mines and Mineral Resources Bulletin, 121, pp.65-71.

733 Campbell, F.W., 1989. Geology and coal resources of Fence Lake 1:50,000 quadrangle, New Mexico. New Mexico Bureau of Mines and Mineral Resources Geologic Map 62. https://geoinfo.nmt.edu/publications/maps/geologic/gm/62/ (Accessed 4 November 2019).

Campbell, F., Roybal, G.H. 1984. Geology and Coal Resources of the Fence Lake 1:50,000 Quadrangle, Catron and Cibola Counties, New Mexico. New Mexico Bureau of Mines

742 Cao, W., Paterson, S., Memeti, V., Mundil, R., Anderson, J.L., Schmidt, K., 2015. Tracking paleodeformation fields in the Mesozoic central Sierra Nevada arc: Implications for intra- 
744

745

746

747

748

749

750

751

752

753

754

755

756

757

758

759

760

761

762

763

764

765

766 arc cyclic deformation and arc tempos. Lithosphere, 7(3), pp.296 - 320. https://doi.org/10.1130/L389.1

Cawood, P.A., Hawkesworth, C.J., Dhuime, B., 2012. Detrital zircon record and tectonic setting. Geology, 40(10), pp.875 - 878. https://doi.org/10.1130/G32945.1

Carpenter, K., 2014. Where the sea meets the land - the unresolved Dakota problem in Utah. Utah Geological Association Publication, 43, pp.357 - 372.

Chaboureau, A.C., Sepulchre, P., Donnadieu, Y., Franc, A., 2014. Tectonic-driven climate change and the diversification of angiosperms. Proceedings of the National Academy of Sciences, 111(39), pp.14066 - 14070. https://doi.org/10.1073/pnas.1324002111

Chamberlin, R.M., Anderson, O.J., 1989. The Laramide Zuni Uplift, southeastern Colorado Plateau - A microcosm of Eurasian-style indentation-extrusion tectonics? In: Anderson, O.J., Lucas, S.G., Love, D.W., Cather, S.M., (Eds.). Southeastern Colorado Plateau: Socorro, New Mexico. New Mexico Geological Society 40 th Annual Fall Field Conference Guidebook, pp.81 - 90.

Chin, K., Estrada-Ruiz, E., Wheeler, E.A., Upchurch Jr, G.R., Wolfe, D.G., 2019. Early angiosperm woods from the mid-Cretaceous (Turonian) of New Mexico, USA: Paraphyllanthoxylon, two new taxa, and unusual preservation. Cretaceous Research, 98, pp.292 - 304. https://doi.org/10.1016/j.cretres.2019.01.017 
768 Chure, D., Britt, B.B., Whitlock, J.A., Wilson, J.A., 2010. First complete sauropod dinosaur skull

769 from the Cretaceous of the Americas and the evolution of sauropod

$770 \quad$ dentition. Naturwissenschaften, 97(4), pp.379-391.

771

772 Cifelli, R.L., Kirkland, J.I., Weil, A., Deino, A.L., Kowallis, B.J., 1997. High-precision

773

774

775

776

777

778

779

780

781

782

783

784

785

786

787

788 40Ar/39Ar geochronology and the advent of North America's Late Cretaceous terrestrial fauna. Proceedings of the National Academy of Sciences, 94(21), pp.11163 - 11167. https://doi.org/10.1073/pnas.94.21.11163

Cifelli, R.L., Nydam, R.L., Gardner, J.D., Weil, A., Eaton, J.G., Kirkland, J.I., Madsen, S.K., 1999. Medial Cretaceous vertebrates from the Cedar Mountain Formation, Emery County, Utah: the Mussentuchit local fauna. In: Gillette, D., (Ed.). Vertebrate paleontology in Utah, Utah Geological Survey Miscellaneous Publication 99(1), pp.219242.

Cobban, W.A., Hook, S.C., 1983. Mid Cretaceous (Turonian) ammonite fauna from Fence Lake area, west-central New Mexico. Memoirs of the Institute of Mining and Technology, New Mexico, 37, 50p.

Cobban, W.A., Walaszczyk, I., Obradovich, J.D., McKinney, K.C., 2006. A USGS zonal table for the Upper Cretaceous middle Cenomanian-Maastrichtian of the Western Interior of 

Geological Survey Open File Report, 1250, 45p.

791

792 Cohen, K.M., Finney, S.C., Gibbard, P.L., Fan, J.X., 2013. The ICS international chronostratigraphic chart. Episodes 36 (3), pp. 199 - 204, v2019/05.

794

795 Condon D.J., Schoene B., McLean N.M., Bowring S.A., Parrish R, 2015. Metrology and traceability of $\mathrm{U}-\mathrm{Pb}$ isotope dilution geochronology (EARTHTIME Tracer Calibration Part I). Geochimica et Cosmochimica Acta 164, pp.464 - 480. https://doi.org/10.1016/j.gca.2015.05.026

799

800 Cook, K.H., Arkell, B., 1987. Geology and Coal Resources of the Mariano Springs Quadrangle, 801 Catron County, New Mexico. New Mexico Bureau of Mines and Mineral Resources Open

802 File Report, 326, 20p.

803

804 Coutts, D.S., Matthews, W.A., Hubbard, S.M., 2019. Assessment of widely used methods to 805 derive depositional ages from detrital zircon populations. Geoscience Frontiers, 10(4),

806 pp.1421 - 1435. https://doi.org/10.1016/j.gsf.2018.11.002

807

808 Craigg, S.D., 2001. Geologic framework of the San Juan structural basin of New Mexico, 809 Colorado, Arizona, and Utah, with emphasis on Triassic through Tertiary rocks. United $810 \quad$ States Geological Survey Professional Paper No. 1420, 65p. 
812 Crowley, J.L., Schoene, B., Bowring, S.A., 2007. U-Pb dating of zircon in the Bishop Tuff at the

813 millennial scale. Geology 35, pp.1123 - 1126. https://doi.org/10.1130/G24017A.1

814

815 Cumella, S.P., 1983. Relation of Upper Cretaceous regressive sandstone units of the San Juan

816 Basin to source area tectonics. In: Reynolds, M.W. and Dolly, E.D., (Eds.). Mesozoic

817 Paleogeography of the West-Central United States: Rocky Mountain Paleogeography

818 Symposium 2. The Rocky Mountain Section (Society for Sedimentary Geology), pp.189-

819199.

820

821 Currie, B.S., 1997. Sequence stratigraphy of nonmarine Jurassic-Cretaceous rocks, central

822 Cordilleran foreland-basin system. Geological Society of America Bulletin, 109(9),

823 pp.1206 - 1222. https://doi.org/10.1130/0016-7606(1997)109<1206:SSONJC>2.3.CO;2

824

825 DeCelles, P.G., 2004. Late Jurassic to Eocene evolution of the Cordilleran thrust belt and

826

827 foreland basin system, western USA. American Journal of Science, 304(2), pp.105 - 168. https://doi.org/10.2475/ajs.304.2.105

828

829 DeCelles, P.G., Coogan, J.C., 2006. Regional structure and kinematic history of the Sevier fold830 and-thrust belt, central Utah. Geological Society of America Bulletin, 118(7-8), pp.841 -

831 864. https://doi.org/10.1130/B25759.1

832

833 DeCelles, P.G., Graham, S.A., 2015. Cyclical processes in the North American Cordilleran orogenic system. Geology, 43(6), pp.499 - 502. https://doi.org/10.1130/G36482.1 
835

836 DeGraaff Surpless, K., Clemens-Knott, D., Barth, A.P., Gevedon, M., 2019. A survey of Sierra

837 Nevada magmatism using Great Valley detrital zircon trace-element geochemistry: View

838 from the forearc. Lithosphere, 11(5), pp.603-619. https://doi.org/10.1130/L1059.1

839

840 D’Emic, M.D., Foreman, B., Jud, N.A., Britt, B.B., Schmitz, M., Crowley, J.L., 2019.

841

Chronostratigraphic revision of the cloverly formation (Lower Cretaceous, Western

842

843 Interior, USA). Bulletin of the Peabody Museum of Natural History, 60(1), pp.3 - 40. https://doi.org/10.3374/014.060.0101

844

845 Dickinson, W.R., 2008. Accretionary Mesozoic-Cenozoic expansion of the Cordilleran 846 continental margin in California and adjacent Oregon. Geosphere, 4(2), pp.329 - 353.

847 https://doi.org/10.1130/GES00105.1

848

Dickinson, W.R., Gehrels, G.E., 2003. U-Pb ages of detrital zircons from Permian and Jurassic eolian sandstones of the Colorado Plateau, USA: paleogeographic

851

852 implications. Sedimentary Geology, 163(1-2), pp.29 - 66. https://doi.org/10.1016/S0037-

853

854 Dickinson, W.R., Gehrels, G.E., 2008. Sediment delivery to the Cordilleran foreland basin:

855 Insights from $\mathrm{U}-\mathrm{Pb}$ ages of detrital zircons in Upper Jurassic and Cretaceous strata of the

856 0738(03)00158-1 Colorado Plateau. American Journal of Science, 308(10), pp.1041 - 1082. https://doi.org/10.2475/10.2008.01 
859 Dickinson, W.R., Gehrels, G.E., 2009a. U-Pb ages of detrital zircons in Jurassic eolian and 860 associated sandstones of the Colorado Plateau: Evidence for transcontinental dispersal $861 \quad$ and intraregional recycling of sediment. Geological Society of America Bulletin, 121(3862 4), pp.408 - 433. https://doi.org/10.1130/B26406.1

863

864 Dickinson, W.R., Gehrels, G.E., 2009b. Use of U-Pb ages of detrital zircons to infer maximum 865 depositional ages of strata: a test against a Colorado Plateau Mesozoic database. Earth and Planetary Science Letters, 288(1-2), pp.115 - 125. https://doi.org/10.1016/j.eps1.2009.09.013

868

Elder, W.P., Kirkland, J.I., 1993. Cretaceous paleogeography of the Colorado Plateau and adjacent areas. Aspects of Mesozoic geology and paleontology of the Colorado Plateau: Museum of Northern Arizona Bulletin, 59, pp.129 - 151.

872

Elder, W.P., Kirkland, J.I., 1994. Cretaceous paleogeography of the southern Western Interior region. In: Caputo, M.V., Peterson, J.A., Franczyk, K.J., (Eds.). Mesozoic Systems of the Rocky Mountain Region, USA. The Rocky Mountain Section (Society for Sedimentary Geology), pp.415-440.

877

878 Farke, A.A., Maxwell, W.D., Cifelli, R.L., Wedel, M.J., 2014. A ceratopsian dinosaur from the Lower Cretaceous of western North America, and the biogeography of Neoceratopsia. PLOS one, 9(12), p.e112055. https://doi.org/10.1371/journal.pone.0112055 
881

882 Finzel, E.S., 2017. Detrital zircon microtextures and U-PB geochronology of Upper Jurassic to Paleocene strata in the distal North American Cordillera foreland basin. Tectonics, 36(7), pp.1295 - 1316. https://doi.org/10.1002/2017TC004549

885

886 Fitz-Diaz, E., Hudleston, P., Tolson, G., 2011. Comparison of tectonic styles in the Mexican and 887 Canadian Rocky Mountain fold-thrust belt. Geological Society, London, Special Publications, 349(1), pp.149 - 167. https://doi.org/10.1144/SP349.8

889

890 Fowler, D.W., 2017. Revised geochronology, correlation, and dinosaur stratigraphic ranges of

891 the Santonian-Maastrichtian (Late Cretaceous) formations of the Western Interior of North America. PloS ONE, 12(11), p.e0188426.

893 https://doi.org/10.1371/journal.pone.0188426

894

895 Fricke, H.C., Foreman, B.Z., Sewall, J.O., 2010. Integrated climate model-oxygen isotope 896 evidence for a North American monsoon during the Late Cretaceous. Earth and Planetary Science Letters, 289(1-2), pp.11-21. https://doi.org/10.1016/j.eps1.2009.10.018

899

900 Gaschnig, R.M., Vervoort, J.D., Lewis, R.S., McClelland, W.C., 2010. Migrating magmatism in 901 the northern US Cordillera: in situ U-Pb geochronology of the Idaho

902 batholith. Contributions to Mineralogy and Petrology, 159(6), pp.863 - 883. https://doi.org/10.1007/s00410-009-0459-5 
904

905 Gaschnig, R.M., Vervoort, J.D., Tikoff, B., Lewis, R.S., 2017. Construction and preservation of

906 batholiths in the northern US Cordillera. Lithosphere, 9(2), pp.315 - 324.

907 https://doi.org/10.1130/L497.1

908

909 Gates, T.A., Horner, J.R., Hanna, R.R., Nelson, C.R., 2011. New unadorned hadrosaurine

910 hadrosaurid (Dinosauria, Ornithopoda) from the Campanian of North America. Journal

911 of Vertebrate Paleontology, 31(4), pp.798-811.

912 https://doi.org/10.1080/02724634.2011.577854

913

914 Gehrels, G., 2014. Detrital zircon U-Pb geochronology applied to tectonics. Annual Review of 915 Earth and Planetary Sciences, 42, pp.127 - 149. https://doi.org/10.1146/annurev-earth$916 \quad 050212-124012$

917

918 Gehrels, G.E., Dickinson, W.R., Ross, G.M., Stewart, J.H., Howell, D.G., 1995. Detrital zircon

919 reference for Cambrian to Triassic miogeoclinal strata of western North

920 America. Geology, 23(9), pp.831 - 834. https://doi.org/10.1130/0091-

$921 \quad$ 7613(1995)023<0831:DZRFCT $>2.3 . C O ; 2$

922

923 Gehrels, G., Pecha, M., 2014. Detrital zircon U-Pb geochronology and Hf isotope geochemistry

924 of Paleozoic and Triassic passive margin strata of western North

$925 \quad$ America. Geosphere, 10(1), pp.49 - 65. https://doi.org/10.1130/GES00889.1

926 
927 Gehrels, G., Rusmore, M., Woodsworth, G., Crawford, M., Andronicos, C., Hollister, L.,

928 Patchett, J., Ducea, M., Butler, R., Klepeis, K., Davidson, C., 2009. U-Th-Pb

929 geochronology of the Coast Mountains batholith in north-coastal British Columbia:

930 Constraints on age and tectonic evolution. Geological Society of America Bulletin, 121(9-

931 10), pp.1341 - 1361. https://doi.org/10.1130/B26404.1

932

933 Gehrels, G.E., Stewart, J.H., 1998. Detrital zircon U-Pb geochronology of Cambrian to Triassic

934 miogeoclinal and eugeoclinal strata of Sonora, Mexico. Journal of Geophysical

935 Research: Solid Earth, 103(B2), pp.2471 - 2487. https://doi.org/10.1029/97JB03251

936

937 Gerstenberger, H., Haase, G., 1997. A highly effective emitter substance for mass spectrometric

938

939 $\mathrm{Pb}$ isotope ratio determinations. Chemical Geology, 136(3-4), pp.309-312. https://doi.org/10.1016/S0009-2541(96)00033-2

940

941 Haq, B.U., 2014. Cretaceous eustasy revisited. Global and Planetary Change, 113, pp.44 - 58.

942 https://doi.org/10.1016/j.gloplacha.2013.12.007

943

944 Hay, W.W., Floegel, S., 2012. New thoughts about the Cretaceous climate and oceans. EarthScience Reviews, 115(4), pp.262 - 272. https://doi.org/10.1016/j.earscirev.2012.09.008

946

947 Hedrick, B.P., Zanno, L.E., Wolfe, D.G., Dodson, P., 2015. The Slothful Claw: Osteology and 948 Taphonomy of Nothronychus mckinleyi and N. graffami (Dinosauria: Theropoda) and 
949

950

951

952

953

954

955

956

957

958

959

960

961

962

963

964

965

966

967

968

969

Anatomical Considerations for Derived Therizinosaurids. PloS ONE, 10(6), p.e0129449. https://doi.org/10.1371/journal.pone.0129449

Herriott, T.M., Crowley, J.L., Schmitz, M.D., Wartes, M.A., Gillis, R.J., 2019. Exploring the law of detrital zircon: LA-ICP-MS and CA-TIMS geochronology of Jurassic forearc strata, Cook Inlet, Alaska, USA. Geology, 47(11), pp.1044 - 1048. https://doi.org/10.1130/G46312.1

Hiess, J., Condon, D.J., McLean, N., Noble, S.R., 2012. 238U/235U systematics in terrestrial uranium-bearing minerals. Science, 335(6076), pp.1610 - 1614. https://doi.org/10.1126/science. 1215507

Hildebrand, R.S., Whalen, J.B., 2014. Arc and slab-failure magmatism in Cordilleran batholiths II-The Cretaceous Peninsular Ranges batholith of southern and Baja California. Geoscience Canada, pp.399 - 458. https://doi.org/10.12789/geocanj.2014.41.059

Hoffman, G.K., 1994. Coal Geology of the Lower Moreno Hill Formation, Salt Lake Field, West Central New Mexico. New Mexico Geological Society Guidebook, 45 th Field Conference, Mogollon Slope, West Central New Mexico and East-Central Arizona, pp.283 - 290. 
970 Hoffman, G.K., 1996. Influence of depositional environment on clay mineralogy in the coal971 bearing lower Moreno Hill Formation, Salt Lake coal field, west-central New Mexico. 972 New Mexico Bureau of Mines and Mineral Resources Open File Report, 427, 22p.

973

974 Hook, S.C., 2010. Flemingostrea elegans, n. sp.: guide fossil to marine, lower Coniacian (Upper 975 Cretaceous) strata of central New Mexico. New Mexico Geology, 32(2), pp.35 - 57.

976

977 Hook, S.C., Cobban, W.A., 2011. The Late Cretaceous oyster Cameleolopha bellaplicata

978 (Shumard 1860), guide fossil to middle Turonian strata in New Mexico. New Mexico 979 Geology, 33(3), pp.67-95.

980

981 Hook, S.C., Cobban, W.A., 2012. Evolution of the Late Cretaceous oyster genus Cameleolopha 982 Vyalov 1936 in central New Mexico. New Mexico Geology, 34, pp.76- 95.

983

984 Hook, S.C., Cobban, W.A., 2013. The Upper Cretaceous (Turonian) Juana Lopez Beds of the D985 Cross Tongue of the Mancos Shale in central New Mexico and their relationship to the 986 987 988

Hook, S.C., Molenaar, C.M., Cobban, W.A., 1983. Stratigraphy and revision of nomenclature of upper Cenomanian to Turonian (Upper Cretaceous) rocks of west-central New Mexico.

991 In: Hook, S.C., (Compiler). Contributions to Mid-Cretaceous Paleontology and 
992

993

994

995

996

997

998

999

1000

1001

1002

1003

1004

1005

1006

1007

1008

1009

1010

1011

1012

1013 Jinnah, Z.A., Roberts, E.M., Deino, A.L., Larsen, J.S., Link, P.K., Fanning, C.M., 2009. New

1014
Stratigraphy of New Mexico, part II. New Mexico Bureau of Mines and Mineral Resources, Circular, 185, pp.7-28.
Huber, B.T., MacLeod, K.G., Watkins, D.K., Coffin, M.F., 2018. The rise and fall of the Cretaceous Hot Greenhouse climate. Global and Planetary Change, 167, pp.1 - 23. https://doi.org/10.1016/j.gloplacha.2018.04.004

Hunt, G.J., Lawton, T.F., Kirkland, J.I., Sprinkel, D.A., Yonkee, W.A., Chidsey, T.C., 2011. Detrital zircon $\mathrm{U}-\mathrm{Pb}$ geochronological provenance of Lower Cretaceous strata, foreland basin, Utah. Sevier Thrust Belt: Northern and Central Utah and Adjacent Areas: Utah Geological Association, Publication, 40, pp.193 - 211.

Hutsky, A.J., Fielding, C.R., 2016. The offshore bar revisited: a new depositional model for isolated shallow marine sandstones in the Cretaceous Frontier Formation of the northern Uinta Basin, Utah, USA. Journal of Sedimentary Research, 86(1), pp.38 - 58. https://doi.org/10.2110/jsr.2015.101

Jaffey, A.H., Flynn, K.F., Glendenin, L.E., Bentley, W.T., Essling, A.M., 1971. Precision measurement of half-lives and specific activities of $U 235$ and $U$ 238. Physical review $C$, 4(5), p.1889. https://doi.org/10.1103/PhysRevC.4.1889 
1015 Kaiparowits formations on the Kaiparowits Plateau, Utah: implications for regional

1016 correlation, provenance, and biostratigraphy. Cretaceous Research, 30(2), pp.287 - 299.

1017 https://doi.org/10.1016/j.cretres.2008.07.012

1018

1019 Joeckel, R.M., Ludvigson, G.A., Möller, A., Hotton, C.L., Suarez, M.B., Suarez, C.A., Sames,

1020 B., Kirkland, J.I., Hendrix, B., 2020. Chronostratigraphy and terrestrial

1021 palaeoclimatology of Berriasian-Hauterivian strata of the Cedar Mountain Formation,

1022 Utah, USA. Geological Society, London, Special Publications, 498(1), pp.75 - 100.

1023 https://doi.org/10.1144/SP498-2018-133

1024

1025 Juárez-Arriaga, E., Lawton, T.F., Ocampo-Díaz, Y.Z.E., Stockli, D.F., Solari, L., 2019. Sediment

1026 provenance, sediment-dispersal systems, and major arc-magmatic events recorded in the

1027 Mexican foreland basin, North-Central and Northeastern Mexico. International Geology

1028 Review, 61(17), pp.2118 - 2142. https://doi.org/10.1080/00206814.2019.1581848

1029

1030 Kauffman, E.G., 1969. Cretaceous marine cycles of the Western Interior. The Mountain

$1031 \quad$ Geologist, 6, pp. $227-245$.

1032

1033 Kauffman, E.G., 1977. Geological and biological overview: Western Interior Cretaceous basin.

1034 The Mountain Geologist, 14, pp. 75 - 99.

1035

1036 Kauffman, E.G., 1984. Paleobiogeography and evolutionary response dynamic in the Cretaceous 1037 Western Interior Seaway of North America. Jurassic - Cretaceous biochronology and 
1038

1039

1040

1041

1042

1043

1044

1045

1046

1047

1048

1049

1050

1051

1052

1053

1054

1055

1056

1057

1058

1059

paleogeography of North America. Geological Association of Canada Special Paper, 27, pp. $273-306$.

Kauffman, E.G., Caldwell, W.G.E., 1993. The Western Interior Basin in space and time. Evolution of the Western Interior Basin. Geological Association of Canada, Special Paper, 39, 30p.

Kauffman, E.G., Hart, M.B., 1996. Cretaceous bio-events. In: Walliser, O.H., (Ed.). Global Events and Event Stratigraphy in the Phanerozoic. Springer-Verlag, Berlin, Heidelberg, pp. $285-312$

Kauffman, E.G., Sageman, B.B., Kirkland, J., Elder, W.P., Harries, P.J., Villamil, T., 1993. Molluscan biostratigraphy of the Cretaceous western interior basin, North America. Evolution of the Western Interior Basin. Geological Association of Canada, Special Paper, 39, pp.397-434.

Kelley, V.C., 1957. Tectonics of the San Juan basin and surrounding areas. Geology of Southwestern San Juan Basin. New Mexico Geological Society 2nd Field Conference Guidebook, pp. $44-52$.

Kelley, V.C., 1967. Tectonics of the Zuni-Defiance region, New Mexico and Arizona. In: Trauger, F. D., (Ed.). Defiance, Zuni, Mt. Taylor Region (Arizona and New Mexico). 
1060

1061

1062

1063

1064

1065

1066

1067

1068

1069

1070

1071

1072

1073

1074

1075

1076

1077

1078

1079

1080

New Mexico Geological Society $18^{\text {th }}$ Annual Fall Field Conference Guidebook, pp.28 31.

Kirkland, J.I., Britt, B., Burge, D.L., Carpenter, K., Cifelli, R., DeCourten, F., Eaton, J., Hasiotis, S., Lawton, T., 1997. Lower to middle Cretaceous dinosaur faunas of the central Colorado Plateau: a key to understanding 35 million years of tectonics, sedimentology, evolution, and biogeography. Brigham Young University Geology Studies, 42, pp.69-104.

Kirkland, J.I., Wolfe, D.G., 2001. First definitive therizinosaurid (Dinosauria; Theropoda) from North America. Journal of Vertebrate Paleontology, 21(3), pp.410 - 414. https://doi.org/10.1671/0272-4634(2001)021[0410:FDTDTF]2.0.CO;2

Kirkland, J.I., Smith, D., Wolfe, D.G., 2005. Holotype braincase of Nothronychus mckinleyi Kirkland and Wolfe, 2001 (Theropoda, Therizinosauridae) from the Upper Cretaceous (Turonian) of West-Central New Mexico. In: Carpenter, K., (Ed.). The Carnivorous Dinosaurs. Indiana University Press, Bloomington, Indiana, pp.87 - 96.

Knapp, J.H., Heizler, M.T., 1990. Thermal history of crystalline nappes of the Maria fold and thrust belt, west central Arizona. Journal of Geophysical Research: Solid Earth, 95(B12), pp.20049 - 20073. https://doi.org/10.1029/JB095iB12p20049 
1081 Krogh, T.E., 1973. A low-contamination method for hydrothermal decomposition of zircon and 1082 extraction of $\mathrm{U}$ and $\mathrm{Pb}$ for isotopic age determinations. Geochimica et Cosmochimica 1083 Acta, 37(3), pp.485 - 494. https://doi.org/10.1016/0016-7037(73)90213-5

1084

1085 LaMaskin, T.A., 2012. Detrital zircon facies of Cordilleran terranes in western North 1086 America. GSA Today, 22(3), pp.4-11. https://doi.org/10.1130/GSATG142A.1

1087

1088 Landis, E. R., McLellan, M. W., McKay, E. J., Carter, M. D., Medlin, A. L., 1985. Geologic map 1089 of the Fence Lake SW quadrangle, Cibola and Catron Counties, New Mexico. United $1090 \quad$ States Geological Survey, Miscellaneous Field Studies Map 1750.

1091 https://ngmdb.usgs.gov/Prodesc/proddesc_7451.htm (Accessed 4 November 2019).

1092

1093 Laskowski, A.K., DeCelles, P.G., Gehrels, G.E., 2013. Detrital zircon geochronology of 1094 Cordilleran retroarc foreland basin strata, western North America. Tectonics, 32(5), 1095 pp.1027 - 1048. https://doi.org/10.1002/tect.20065

1096

1097 Laurin, J., Barclay, R.S., Sageman, B.B., Dawson, R.R., Pagani, M., Schmitz, M., Eaton, J., 1098 McInerney, F.A., McElwain, J.C., 2019. Terrestrial and marginal-marine record of the 1099 mid-Cretaceous Oceanic Anoxic Event 2 (OAE 2): High-resolution framework, carbon 1100 isotopes, CO2 and sea-level change. Palaeogeography, Palaeoclimatology, 1101 Palaeoecology, 524, pp.118 - 136. https://doi.org/10.1016/j.palaeo.2019.03.019 1102 
1103 Lawton, T.F., 2019. Chapter 13: Laramide Sedimentary Basins and Sediment-Dispersal Systems.

1104 In: Miall, A.D., (Ed.). The Sedimentary Basins of the United States and Canada, Elsevier, $1105 \quad$ pp. $529-557$ https://doi.org/10.1016/B978-0-444-63895-3.00013-9

1106

1107 Lawton, T.F., Bradford, B.A., 2011. Correlation and provenance of Upper Cretaceous

1108 (Campanian) fluvial strata, Utah, USA, from zircon U-Pb geochronology and

1109 petrography. Journal of Sedimentary Research, 81(7), pp.495 - 512.

$1110 \quad$ https://doi.org/10.2110/jsr.2011.45

1111

1112 Lawton, T.F., Hunt, G.J., Gehrels, G.E., 2010. Detrital zircon record of thrust belt unroofing in

1113 Lower Cretaceous synorogenic conglomerates, central Utah. Geology, 38(5), pp.463 -

1114 466. https://doi.org/10.1130/G30684.1

1115

1116 Lawton, T.F., Pollock, S.L., Robinson, R.A.J., 2003. Integrating sandstone petrology and nonmarine sequence stratigraphy: Application to the Late Cretaceous fluvial systems of

1119 southwestern Utah, USA. Journal of Sedimentary Research, 73(3), pp.389 - 406.

1120

1121 Lin, W., Bhattacharya, J.P., 2019. Depositional facies and the sequence stratigraphic control of a

1122 mixed-process influenced clastic wedge in the Cretaceous Western Interior Seaway: The

1123 Gallup System, New Mexico, USA. Sedimentology. https://doi.org/10.1111/sed.12667

1124 
1125 Lin, W., Bhattacharya, J.P., Stockford, A., 2019. High-resolution Sequence Stratigraphy and

1126 Implications For Cretaceous Glacioeustasy of the Late Cretaceous Gallup System, New

1127 Mexico, USA. Journal of Sedimentary Research, 89(6), pp.552 - 575.

$1128 \quad$ https://doi.org/10.2110/jsr.2019.32

1129

1130 Linde, G.M., Trexler Jr, J.H., Cashman, P.H., Gehrels, G., Dickinson, W.R., 2016. Detrital

1131 zircon U-Pb geochronology and $\mathrm{Hf}$ isotope geochemistry of the Roberts Mountains

1132 allochthon: New insights into the early Paleozoic tectonics of western North

$1133 \quad$ America. Geosphere, 12(3), pp.1016 - 1031. https://doi.org/10.1130/GES01252.1

1134

1135 Lloyd, G.T., Davis, K.E., Pisani, D., Tarver, J.E., Ruta, M., Sakamoto, M., Hone, D.W.,

1136 Jennings, R., Benton, M.J., 2008. Dinosaurs and the Cretaceous Terrestrial Revolution.

1137 Proceedings of the Royal Society of London B: Biological Sciences, 275(1650), pp.2483

$1138-2490$. https://doi.org/10.1098/rspb.2008.0715

1139

1140 Lowery, C.M., Leckie, R.M., Bryant, R., Elderbak, K., Parker, A., Polyak, D.E., Schmidt, M.,

1141 Snoeyenbos-West, O., Sterzinar, E., 2018. The Late Cretaceous Western Interior Seaway

1142 as a model for oxygenation change in epicontinental restricted basins. Earth-Science

1143 Reviews, 177, pp.545 - 564. https://doi.org/10.1016/j.earscirev.2017.12.001

1144

1145 Ludwig, K.R., 2003. Isoplot/Ex version 3.00/4.13. A geochronological toolkit for Microsoft

$1146 \quad$ Excel. Berkeley Geochronology Center Special Publication, 4. 
1148 Mack, G.H., 1992. Paleosols as an indicator of climatic change at the early-Late Cretaceous

1149 boundary, southwestern New Mexico. Journal of Sedimentary Research, 62(3), pp.483 -

1150 494. https://doi.org/10.1306/D426792E-2B26-11D7-8648000102C1865D

1151

1152 MacNaughton, R.B., Moynihan, D.P., Roots, C.F., Crowley, J.L., 2016. New occurrences of

1153 Oldhamia in eastern Yukon, Canada: Stratigraphic context and implications for Cambrian

1154 deep-marine biostratigraphy. Ichnos, 23(1-2), pp.33 - 52.

1155 https://doi.org/10.1080/10420940.2015.1127232

1156

1157 Mattinson, J.M., 2005. Zircon U-Pb chemical abrasion (“CA-TIMS”) method: combined

1158 annealing and multi-step partial dissolution analysis for improved precision and accuracy

1159 of zircon ages. Chemical Geology, 220(1-2), pp.47 -- 66.

1160 https://doi.org/10.1016/j.chemgeo.2005.03.011

1161

1162 McDonald, A.T., Wolfe, D.G., Kirkland, J.I., 2006. On a hadrosauromorph (Dinosauria:

1163 Ornithopoda) from the Moreno Hill Formation (Cretaceous, Turonian) of New Mexico.

1164 New Mexico Museum of Natural History and Science Bulletin, 35, pp. 277 - 279.

1165

1166 McDonald, A.T., Wolfe, D.G., Kirkland, J.I., 2010. A new basal hadrosauroid (Dinosauria:

1167 Ornithopoda) from the Turonian of New Mexico. Journal of Vertebrate Paleontology,

1168 30(3), pp.799 - 812. https://doi.org/10.1080/02724631003763516

1169 
1170 McDonough, K. J., Cross, T. A., 1991. Late Cretaceous sea level from a paleoshoreline. Journal of Geophysical Research, (96)(B), pp. 6591-6607. https://doi.org/10.1029/91JB00281

1172

1173 McLellan, M., Haschke, L., Robinson, L., Carter, M.D., Medlin, A., 1983a. Middle Turonian and 1174 younger Cretaceous rocks, northern Salt Lake coal field, Cibola and Catron Counties,

1175 New Mexico. In: Hook, S.C., (Compiler). Contributions to Mid-Cretaceous Paleontology 1176 and Stratigraphy of New Mexico, part II. New Mexico Bureau of Mines and Mineral $1177 \quad$ Resources, Circular, 185, pp.41-47.

1178

1179 McLellan, M., Haschke, L., Robinson, L., Landis, E.R., 1983b. Geologic map of the Moreno Hill 1180 quadrangle, Cibola and Catron Counties, New Mexico. United States Geological Survey, $1181 \quad$ Miscellaneous Field Studies Map 1509.

1182 https://ngmdb.usgs.gov/Prodesc/proddesc_7301.htm (Accessed 17 December 2020).

1183

1184 McLellan, M., Landis, E.R., Biewick, L.H., 1984. Stratigraphic framework, structure, and 1185 general geology of the Salt Lake Coal Field, Cibola and Catron counties, New Mexico.

1188

1189 McLellan, M., Robinson, L., Haschke, L., Carter, M.D., Medlin, A., 1982. Fence Lake 1190 Formation (Tertiary), west-central New Mexico. New Mexico Geology, 4(4), pp.53 - 55. 1191 
1192 Meyers, S.R., Siewert, S.E., Singer, B.S., Sageman, B.B., Condon, D.J., Obradovich, J.D., Jicha,

1193 B.R., Sawyer, D.A., 2012. Intercalibration of radioisotopic and astrochronologic time

1194 scales for the Cenomanian-Turonian boundary interval, Western Interior Basin,

1195 USA. Geology, 40(1), pp.7 - 10. https://doi.org/10.1130/G32261.1

1196

1197 Miall, A.D., Catuneanu, O., 2019. Chapter 9: The Western Interior Basin. In: Miall, A.D., (Ed.).

1198 The Sedimentary Basins of the United States and Canada, Elsevier, pp.401 - 443.

1200 Miall, A.D., Catuneanu, O., Vakarelov, B.K., Post, R., 2008. The Western Interior Basin.

1201 Sedimentary Basins of the World, 5, Elsevier, pp.329-362.

1202

1203 Molenaar, C.M., 1983a. Major Depositional Cycles and Regional Correlations of Upper

1204 Cretaceous Rocks, Southern Colorado Plateau and Adjacent Areas. In: Reynolds, M.W.,

1205 Dolly, E.D., (Eds.). Mesozoic Paleogeography of the West-Central United States: Rocky

1206 Mountain Paleogeography Symposium 2. The Rocky Mountain Section (Society for

$1207 \quad$ Sedimentary Geology), pp.201-224.

1208

1209 Molenaar, C.M., 1983b. Principal reference section and correlation of Gallup Sandstone,

1210 northwestern New Mexico. In: Hook, S.C., (Compiler). Contributions to Mid-Cretaceous

1211 Paleontology and Stratigraphy of New Mexico, part II: New Mexico Bureau of Mines and

1212 Mineral Resources Circular, 185, pp.29-40.

1213 
1214 Molenaar, C.M., Cobban, W.A., Merewether, E.A., Pillmore, C.L., Wolfe, D.G., Holbrook, J.M.

1215 2002. Regional Stratigraphic Cross Sections of Cretaceous Rocks from East-Central

1216 Arizona to the Oklahoma Panhandle. Miscellaneous Field Studies Map MF-2382. United

1217 States Geological Survey. https://doi.org/10.3133/mf2382

1218

1219 Nesbitt, S.J., Denton, R.K., Loewen, M.A., Brusatte, S.L., Smith, N.D., Turner, A.H., Kirkland, 1220 J.I., McDonald, A.T., Wolfe, D.G., 2019. A mid-Cretaceous tyrannosauroid and the 1221 origin of North American end-Cretaceous dinosaur assemblages. Nature Ecology \& 1222 Evolution, 3(6), pp.892 - 902. https://doi.org/10.1038/s41559-019-0888-0

1223

1224 New Mexico Bureau of Geology and Mineral Resources, 2003. Geologic Map of New Mexico, 1225 1:500,000. New Mexico Bureau of Geology and Mineral Resources.

1226 https://geoinfo.nmt.edu/publications/maps/geologic/state/home.cfml (Accessed 4 $1227 \quad$ November 2019).

1228

1229 Normore, L.S., Zhen, Y.Y., Dent, L.M., Crowley, J.L., Percival, I.G., Wingate, M.T.D., 2018.

1230 Early Ordovician CA-IDTIMS U-Pb zircon dating and conodont biostratigraphy, 1231 Canning Basin, Western Australia. Australian Journal of Earth Sciences, 65(1), pp.61 1232 73. https://doi.org/10.1080/08120099.2018.1411292

1233

1234 Obradovich, J.D., 1993. A Cretaceous time scale. In: Caldwell, W.G.E., Kauffman, E.G., (Eds.). 1235 Evolution of the Western Interior Basin. Geological Association of Canada, Special $1236 \quad$ Paper, 39, pp.379-396. 
1238 Ogg, J.G., Hinnov, L.A., 2012. Cretaceous. In: Gradstein, F.M., Ogg, J.G., Schmitz, M.D., Ogg, 1239 G., (Eds.). The Geologic Time Scale 2012, Volume 2. Elsevier, pp.793 - 883.

1241 Pană, D.I., Poulton, T.P., DuFrane, S.A., 2019. U-Pb detrital zircon dating supports Early 1242 Jurassic initiation of the Cordilleran foreland basin in southwestern Canada. Geological $1243 \quad$ Society of America Bulletin, 131(1-2), pp.318 - 334.

Parrish, J.T., Gaynor, G.C., Swift, D.J.P., 1984. Circulation in the Cretaceous Western Interior seaway of North America, a review. In: The Mesozoic of Middle North America: A Selection of Papers from the Symposium on the Mesozoic of Middle North America, Calgary, Alberta, Canada. Canadian Society of Petroleum Geologists Memoir 9, pp. 221 $-231$.

1250

1251 Pecha, M.E., Gehrels, G.E., Karlstrom, K.E., Dickinson, W.R., Donahue, M.S., Gonzales, D.A., Blum, M.D., 2018. Provenance of Cretaceous through Eocene strata of the Four Corners region: Insights from detrital zircons in the San Juan Basin, New Mexico and Colorado. Geosphere, 14(2), pp.785 - 811. https://doi.org/10.1130/GES01485.1

Pike, W.S., 1947. Intertonguing marine and nonmarine Upper Cretaceous deposits of New Mexico, Arizona, and southwestern Colorado. Geological Society of America Memoir 24, pp. $1-103$. 
1260 Quinn, G.M., Hubbard, S.M., Putnam, P.E., Matthews, W.A., Daniels, B.G., Guest, B., 2018. A

1261 Late Jurassic to Early Cretaceous record of orogenic wedge evolution in the Western

1262 Interior basin, USA and Canada. Geosphere, 14(3), pp.1187-1206.

$1263 \quad$ https://doi.org/10.1130/GES01606.1

1264

1265 Rinke-Hardekopf, L., Dashtgard, S.E., MacEachern, J.A., 2019. Earliest Cretaceous

1266

1267

1268 Transgression of North America Recorded in Thick Coals: McMurray Sub-Basin,

1269

Roberts, L.N.R., Kirschbaum, M.A., 1995. Paleogeography and the Late Cretaceous of the Canada. International Journal of Coal Geology, 204, pp.18 - 33. https://doi.org/10.1016/j.coal.2019.01.011

1274

1275

1276

1277

1278

1279

1280

1281

1282 Western Interior of middle North America; coal distribution and sediment accumulation. United States Geological Survey Professional Paper No. 1561, 115p. https://doi.org/10.3133/pp1561

Roberts, E.M., Sampson, S.D., Deino, A.L., Bowring, S.A., Buchwaldt, R., 2013. The Kaiparowits Formation: a remarkable record of Late Cretaceous terrestrial environments, ecosystems, and evolution in western North America. At the Top of the Grand Staircase: The Late Cretaceous of Southern Utah. Indiana University Press, Bloomington, Indiana, pp. $85-106$.

Ross, J.B., Ludvigson, G.A., Möller, A., Gonzalez, L.A., Walker, J.D., 2017. Stable isotope paleohydrology and chemostratigraphy of the Albian Wayan Formation from the wedge- 
top depozone, North American Western Interior Basin. Science China Earth Sciences, 60(1), pp.44 - 57. https://doi.org/10.1007/s11430-016-0087-5

1285

Rossignol, C., Hallot, E., Bourquin, S., Poujol, M., Jolivet, M., Pellenard, P., Ducassou, C., Nalpas, T., Heilbronn, G., Yu, J., Dabard, M.P., 2019. Using volcaniclastic rocks to constrain sedimentation ages: To what extent are volcanism and sedimentation synchronous?. Sedimentary Geology, 381, pp.46 - 64 . https://doi.org/10.1016/j.sedgeo.2018.12.010

1291

Roybal, G.H., 1982. Geology and coal resources of Tejana Mesa quadrangle. New Mexico Bureau of Mines and Mineral Resources, Open File Report, 178, 39p.

Salem, A.C., 2009. Mesozoic tectonics of the Maria fold and thrust belt and McCoy basin: an examination of polyphase deformation and synorogenic response (Ph.D Thesis). University of New Mexico, Albuquerque, New Mexico, 260p.

Sauer, K.B., Gordon, S.M., Miller, R.B., Vervoort, J.D., Fisher, C.M., 2017. Evolution of the Jura-Cretaceous North American Cordilleran margin: Insights from detrital-zircon U-Pb and Hf isotopes of sedimentary units of the North Cascades Range,

1304 Schmitz, M.D., Schoene, B., 2007. Derivation of isotope ratios, errors, and error correlations for 1305 $\mathrm{U}-\mathrm{Pb}$ geochronology using 205Pb-235U-(233U)-spiked isotope dilution thermal 
1306

1307

1308

1309

1310

1311

1312

1313

1314

1315

1316

1317

1318

1319

1320

1321

1322

1323

1324 Sweeney, I.J., Chin, K., Hower, J.C., Budd, D.A., Wolfe, D.G. 2009. Fossil wood from the 1325

1327

1328

ionization mass spectrometric data. Geochemistry, Geophysics, Geosystems, 8(8), 20 p. https://doi.org/10.1029/2006GC001492

Sláma, J., Košler, J., Condon, D.J., Crowley, J.L., Gerdes, A., Hanchar, J.M., Horstwood, M.S., Morris, G.A., Nasdala, L., Norberg, N., Schaltegger, U., 2008. Plešovice zircon - a new natural reference material for $\mathrm{U}-\mathrm{Pb}$ and $\mathrm{Hf}$ isotopic microanalysis. Chemical Geology, 249(1-2), pp.1 - 35. https://doi.org/10.1016/j.chemgeo.2007.11.005

Slingerland, R., Kump, L.R., Arthur, M.A., Fawcett, P.J., Sageman, B.B., Barron, E.J., 1996. Estuarine circulation in the Turonian western interior seaway of North America. Geological Society of America Bulletin, 108(8), pp.941 - 952. https://doi.org/10.1130/0016-7606(1996)108<0941:ECITTW>2.3.CO;2

Spencer, J.E., Reynolds, S.J., 1990. Relationship between Mesozoic and Cenozoic tectonic features in west central Arizona and adjacent southeastern California. Journal of Geophysical Research: Solid Earth, 95(B1), pp.539 - 555. https://doi.org/10.1029/JB095iB01p00539 middle Cretaceous Moreno Hill Formation: Unique expressions of wood mineralization and implications for the processes of wood preservation. International Journal of Coal Geology, 79(1-2), pp.1 - 17p. https://doi.org/10.1016/j.coal.2009.04.001 
1329 Szwarc, T.S., Johnson, C.L., Stright, L.E., McFarlane, C.M., 2015. Interactions between axial

1330 and transverse drainage systems in the Late Cretaceous Cordilleran foreland basin:

1331 evidence from detrital zircons in the Straight Cliffs Formation, southern Utah,

1332 USA. Geological Society of America Bulletin, 127(3-4), pp.372 - 392.

$1333 \quad$ https://doi.org/10.1130/B31039.1

1334

1335 Titus, A.L., Roberts, E.M., Albright III, L.B., 2013. Geologic overview. At the Top of the Grand

1336 Staircase: The Late Cretaceous of Southern Utah. Indiana University Press,

1337 Bloomington, Indiana, pp.13-41.

1338

1339 Trumbull, J., 1960, Coal Fields of the United States (sheet 1): United States Geological Survey

1340 Map, scale 1:5,000,000. In: McLellan, M., Haschke, L., Robinson, L., Carter, M.D.,

1341 Medlin, A., 1983. Middle Turonian and younger Cretaceous rocks, northern Salt Lake

1342 coal field, Cibola and Catron Counties, New Mexico. In: Hook, S.C., (Compiler).

1343 Contributions to Mid-Cretaceous Paleontology and Stratigraphy of New Mexico, part II:

1344 New Mexico Bureau of Mines and Mineral Resources, Circular, 185, pp.41 - 47.

1345

1346 Tucker, R.T., Roberts, E.M., Hu, Y., Kemp, A.I., Salisbury, S.W., 2013. Detrital zircon age

1347 constraints for the Winton Formation, Queensland: contextualizing Australia's Late

$1348 \quad$ Cretaceous dinosaur faunas. Gondwana Research, 24(2), pp.767 - 779.

1349 https://doi.org/10.1016/j.gr.2012.12.009

1350 
1351 Tucker, R.T., Roberts, E.M., Henderson, R.A., Kemp, A.I., 2016. Large igneous province or

$1352 \quad$ long-lived magmatic arc along the eastern margin of Australia during the Cretaceous?

1353 Insights from the sedimentary record. Geological Society of America Bulletin, 128(9-10),

1354 pp.1461 - 1480. https://doi.org/10.1130/B31337.1

1355

1356 Tucker, R.T., Zanno, L.E., Huang, H.Q., Makovicky, P.J., 2020. A refined temporal framework

1357 for newly discovered fossil assemblages of the upper Cedar Mountain Formation

1358 (Mussentuchit Member), Mussentuchit Wash, Central Utah. Cretaceous Research, 110,

1359 p.104384. https://doi.org/10.1016/j.cretres.2020.104384

1360

1361 Van Schmus, W.R., Bickford, M.E., Turek, A., 1996. Proterozoic geology of the east-central

1362 Midcontinent basement. In: Van der Pluijm, B.A., Catacosinos, P.A., (Eds.). Basement

1363 and Basins of Eastern North America. Geological Society of America Special Paper 308,

$1364 \quad$ pp. $7-32$.

1365

1366 Watson, E.B., Wark, D.A., Thomas, J.B., 2006. Crystallization thermometers for zircon and

1367 rutile. Contributions to Mineralogy and Petrology, 151(4), pp.413 - 433.

1368 https://doi.org/10.1007/s00410-006-0068-5

1369

1370 Whitmeyer, S.J., Karlstrom, K.E., 2007. Tectonic model for the Proterozoic growth of North

1371 America. Geosphere, 3(4), pp.220 - 259. https://doi.org/10.1130/GES00055.1

1372 
1373 White, T., Furlong, K., Arthur, M., 2002. Forebulge migration in the Cretaceous Western Interior 1374 basin of the central United States. Basin Research, 14(1), pp.43 - 54.

1375 https://doi.org/10.1046/j.1365-2117.2002.00165.x

1376

1377 Willis, G.C., 1999. The Utah thrust system-an overview. Geology of Northern Utah and Vicinity, $1378 \quad$ pp. $1-10$.

1379

1380 Wolfe, D.G., 1989. The stratigraphy and paleoenvironments of middle Cretaceous strata along 1381 the central Arizona-New Mexico border (M.Sc. thesis). University of Boulder, Colorado, $1382 \quad 222 \mathrm{p}$.

1383

1384 Wolfe, D.G., Kirkland, J.I., 1998. Zuniceratops christopheri n. gen. \& n. sp., a ceratopsian 1385 dinosaur from the Moreno Hill Formation (Cretaceous, Turonian) of west-central New Mexico. Lower and Middle Cretaceous Terrestrial Ecosystems. New Mexico Museum of

1389 Wolfe, D.G., Kirkland, J.I., Denton, R., Anderson, B.G., 1997. A new terrestrial vertebrate record from the Moreno Hill Formation (Turonian, Cretaceous), west-central New Mexico. Journal of Vertebrate Paleontology, 17(3), p.85A.

1393 Wolfe, D.G., Kirkland, J.I., Smith, D., Poole, K., Chinnery-Algeier, B., McDonald, A., 2007. 1394 Zuniceratops christopheri: An update on the North American ceratopsid sister taxon, Zuni Basin, west-central New Mexico. In: Bruman, D.R., (Compiler). Ceratopsian 
1396

1397

1398

1399

1400

1401

1402

1403

1404

1405

1406

1407 Zanno, L.E., Makovicky, P.J., 2011. On the earliest record of Cretaceous tyrannosauroids in 1408

1411

1412 Zanno, L.E., Makovicky, P.J., 2013. Neovenatorid theropods are apex predators in the Late 1413 Cretaceous of North America. Nature Communications, 4(1), pp.1-9.

1414 https://doi.org/10.1038/ncomms3827

Symposium: Short Papers, Abstracts, and Programs, Royal Tyrell Museum of Paleontology, Drumheller, Alberta, pp. 159 - 167.

Wolfe, D.G., Wolfe, H.D., 2016. Trackway evidence for a theropod group attack upon a possible ceratopsian dinosaur from the Moreno Hill Formation (Turonian) New Mexico. Journal of Vertebrate Paleontology Program Abstracts 2016, p.253.

Yonkee, W.A., Weil, A.B., 2015. Tectonic evolution of the Sevier and Laramide belts within the North American Cordillera orogenic system. Earth-Science Reviews, 150, pp.531 - 593. https://doi.org/10.1016/j.earscirev.2015.08.001 western North America: implications for an Early Cretaceous Laurasian interchange event. Historical Biology: An International Journal of Paleobiology, 23(4), pp.317 - 325. https://doi.org/10.1080/08912963.2010.543952

1415 


\section{Figure 1}

Location map

(A) Map of Colorado Plateau and adjacent areas (modified from Molenaar, 1983a and

Dickinson, 2012); (B) Map of the Zuni Basin and exposure of the Atarque Sandstone and Moreno Hill Formation (modified after Trumbull, 1960; McLellan et al., 1983b; New Mexico Bureau of Geology and Mineral Resources, 2003; Pecha et al., 2018, and references therein). Note: UB - Uinta Basin; HB - Henry Basin; KB - Kaiparowits Basin; RB - Raton Basin; SJB - San Juan Basin; BMB - Black Mesa Basin; ZB - Zuni Basin; AB - Acoma Basin; McC- McCoy Basin; BB - Bisbee Basin; D - Defiance Uplift; MH - Mogollon Highlands; MF\&TB - Maria Fold and Thrust Belt. 


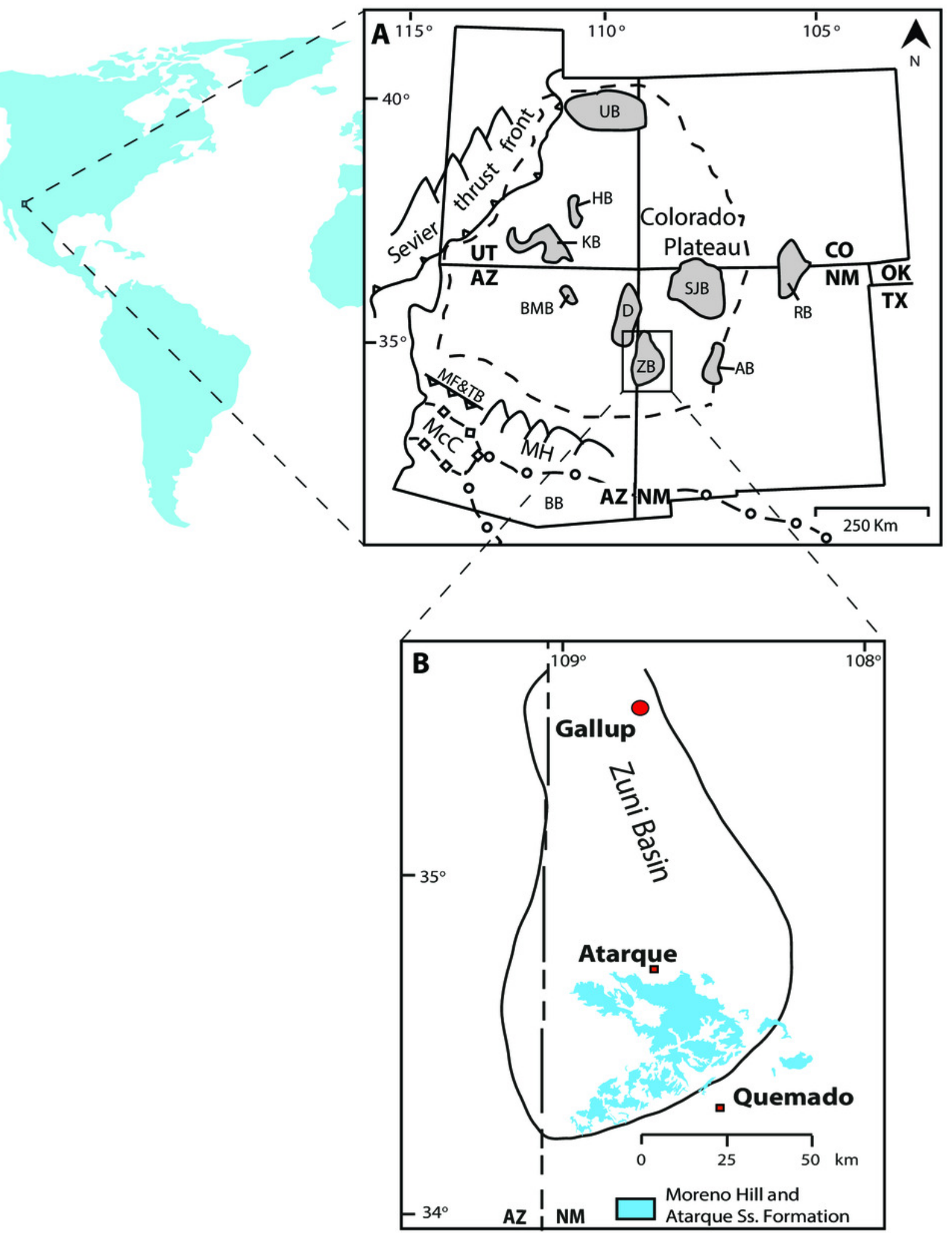




\section{Figure 2}

Stratigraphic column of the Moreno Hill Formation

The Moreno Hill Formation with the underlying Atarque Sandstone, underlying unsurveyed marine units and basal Cretaceous Dakota Sandstone along with the unconformably overlying Fence Lake Formation. Key stratigraphic levels sampled for detrital zircon include: 1) Dakota Sandstone; 2) lower Moreno Hill (Cox 2); 3) middle Moreno Hill (Cox 3); and 4) upper Moreno Hill (Cox 4). Whilst this stratigraphic column is based on our own measurements and observations the original type section and principle reference section stratigraphic columns for the Moreno Hill Formation were designated by McLellan et al., 1983a. 


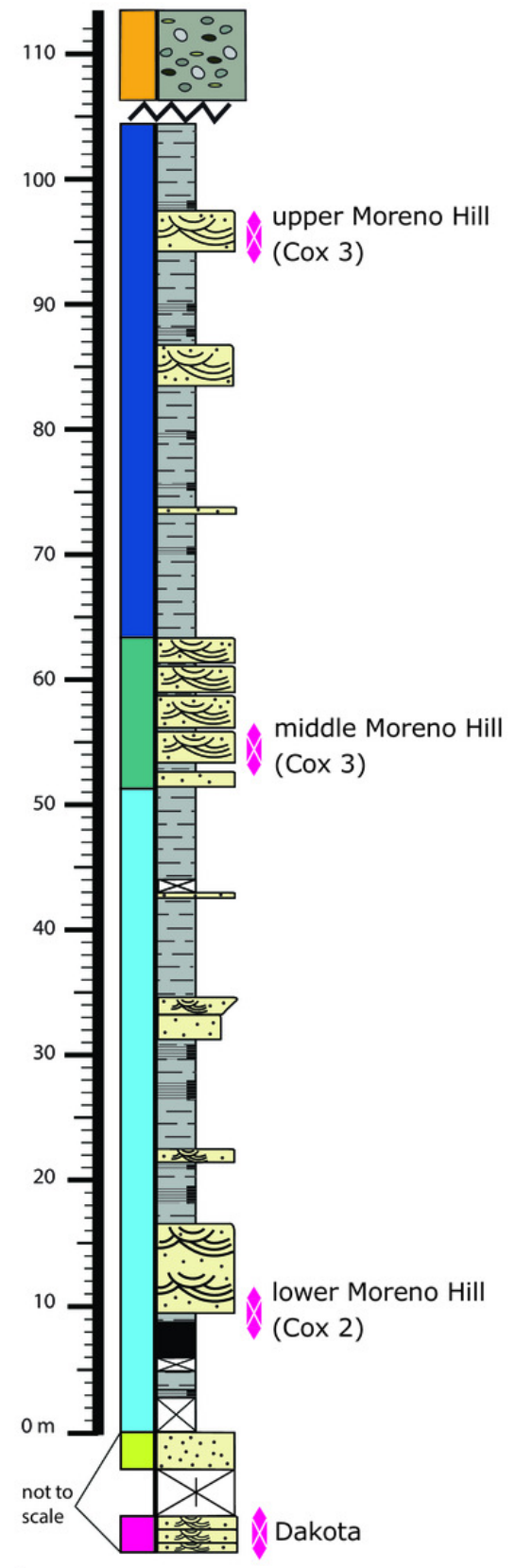

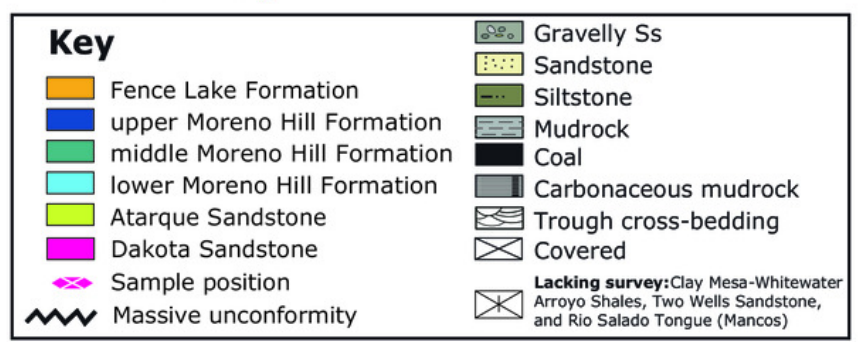


Figure 3

Cathodoluminescence images of zircons

Grains selected for LA-ICPMS \& CA-TIMS are shown with LA-ICP-MS spots and analysis labels. 

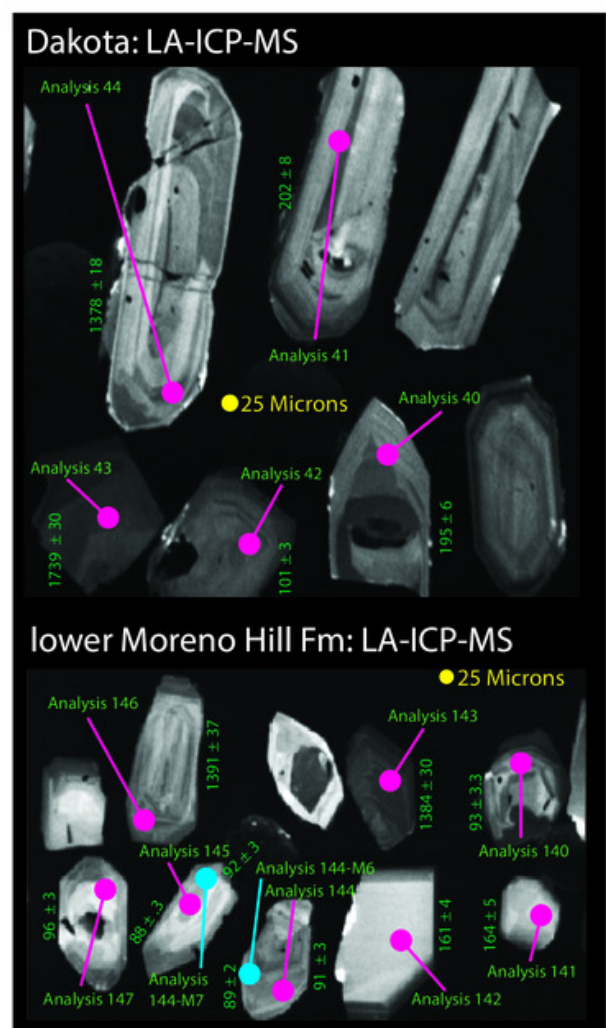

upper Moreno Hill Fm: LA-ICP-MS

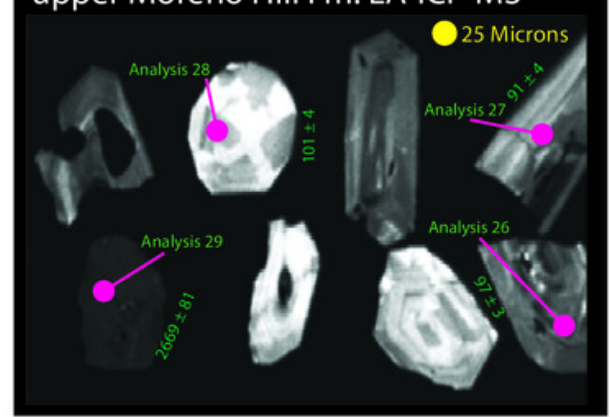




\section{Figure 4}

\section{LA-ICPMS MDA}

Temporal relationship of the five (5) metrics (YDZ, Weighted Average, YC2 $\sigma$, TuffZirc, and YSP) utilized within this study, within stratigraphic order. YDZ, Weighted Average and TuffZirc were run via Isoplot 4.15 (Ludwig, 2003), YC2 $\sigma$ via Age Pick Program (2010) G. Gehrels 1 September 2009, Arizona Laserchron Center, and YSP via Herriott et al. (2019). Also displayed is the K-S test to show the variable weak genetic relationship across the samples across the stratigraphic section. K-S analysis after Barbeau et al., 2009b. 


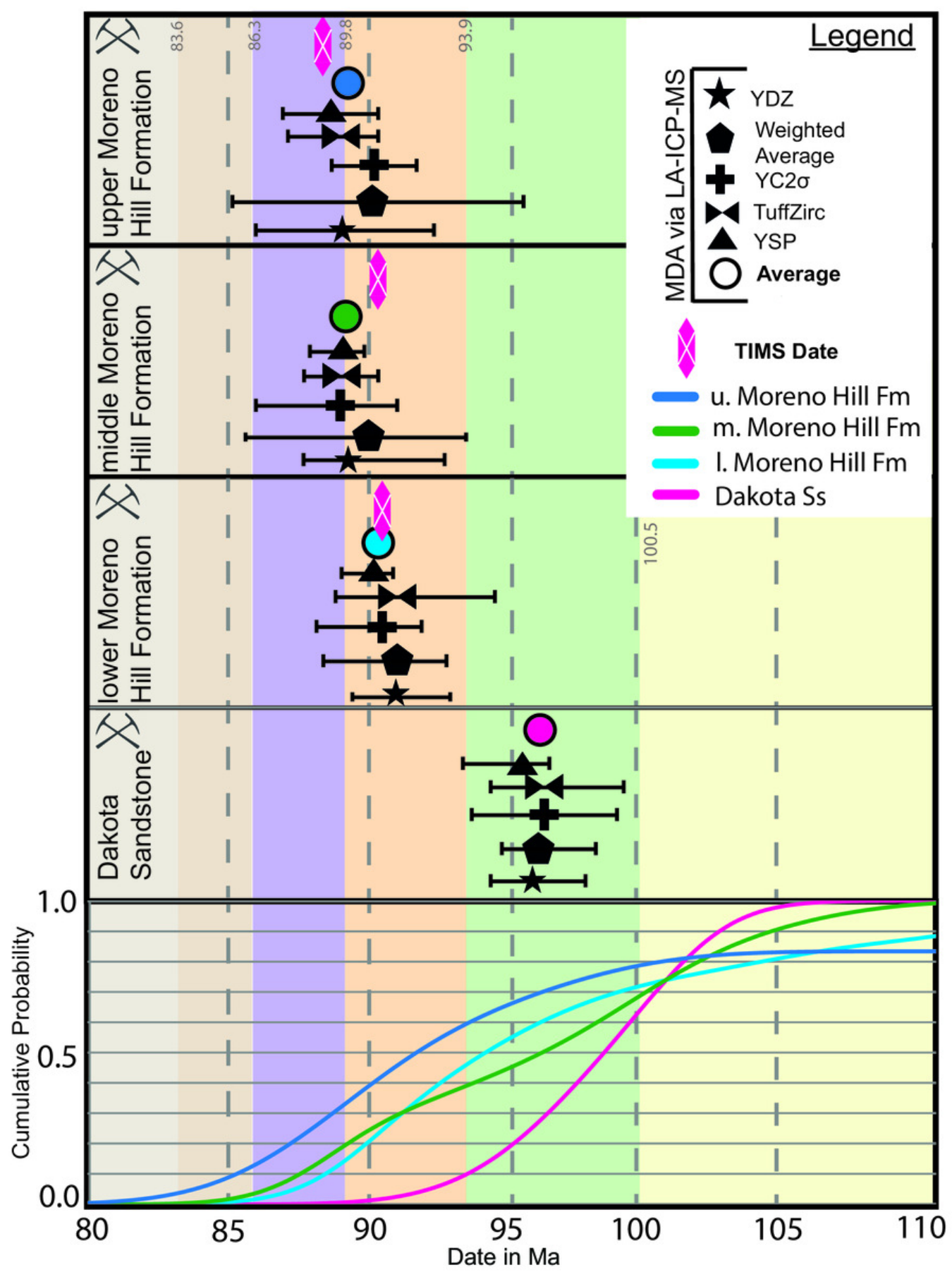




\section{Figure 5}

Detrital zircon provenance

Combined possible crustal provenances and age-distribution curve for all analyzed detrital zircons from the Dakota Sandstone and the three Moreno Hill Formation samples. North American map displays likely crustal provenances for each major and minor detrital zircon age population reworked within the Cordilleran retroarc foreland basin system. Successive zircon age populations (displayed in the age-distribution curve on the right; and are displayed with color corresponding to the select crustal provinces). Modified and adapted from Dickinson and Gehrels (2009b) and Laskowski et al. (2013); and references therein. Age placement based on Cohen et al. (2013, v2019/05). Figure also modified from Tucker et al. (2020). Probability density plots via Isoplot 4.15 (Ludwig, 2003). 


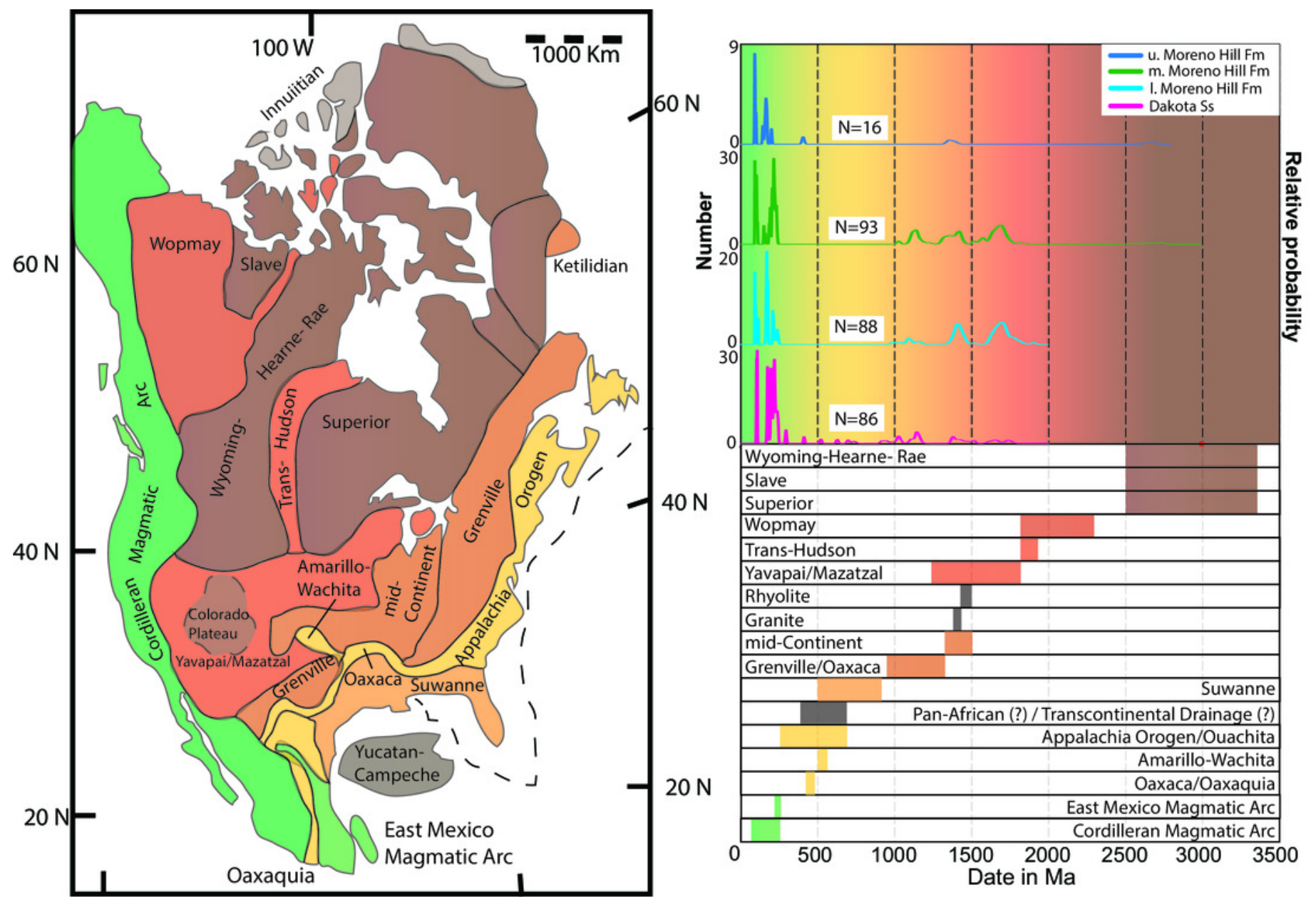




\section{Figure 6}

Youthful detrital zircon provenance

Plausible sources for the most youthful detrital zircon populations recovered within this study. Samples fall within phase B and C, with the most youthful populations in phase C. Information of various inliers recovered from Dickinson and Gehrels (2009b); Gaschnig et al. (2010); Lawton et al. (2010); Hunt et al. (2011); Laskowski et al. (2013); DeCelles and Graham (2015); Linde et al. (2016); Sauer et al. (2017); Brown, Hart \& Stuck (2018); and references therein. Age placement based on Cohen et al. (2013, v2019/05). K-S analysis after Barbeau et al., 2009b. 


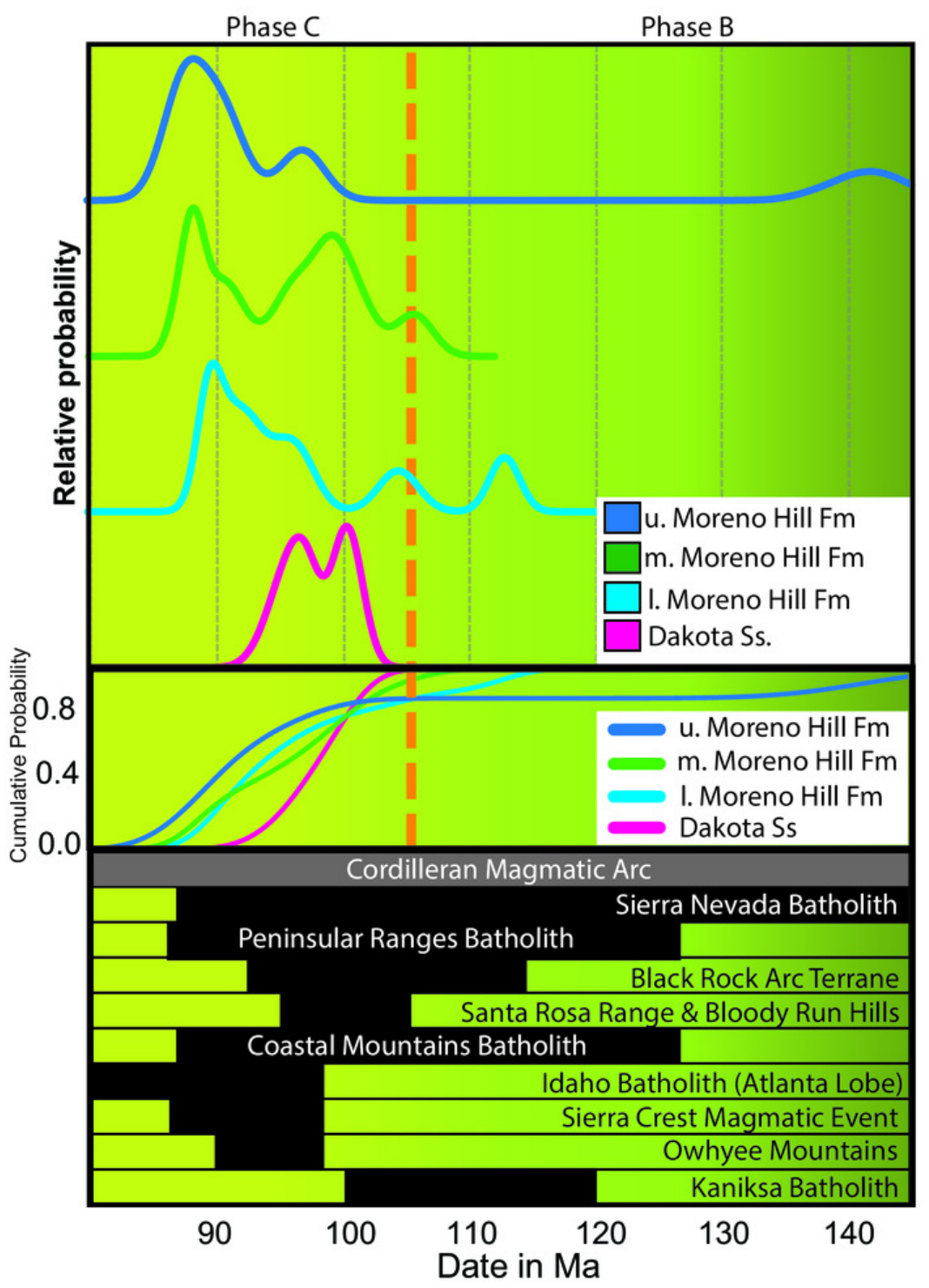




\section{Figure 7}

Continental setting via cumulative proportion curves

Image A) Plot of the general field for Convergent, Collisional, and Extensional Basins based on and modified from Cawood, Hawkesworth \& Dhuime (2012; Fig. 3, p. 877). Images B, C and D) Plots display genetic relationships between samples; similarity is noted where $p$ values are $>0.05$ as shown graphically above. K-S analysis after Barbeau et al., 2009b. 


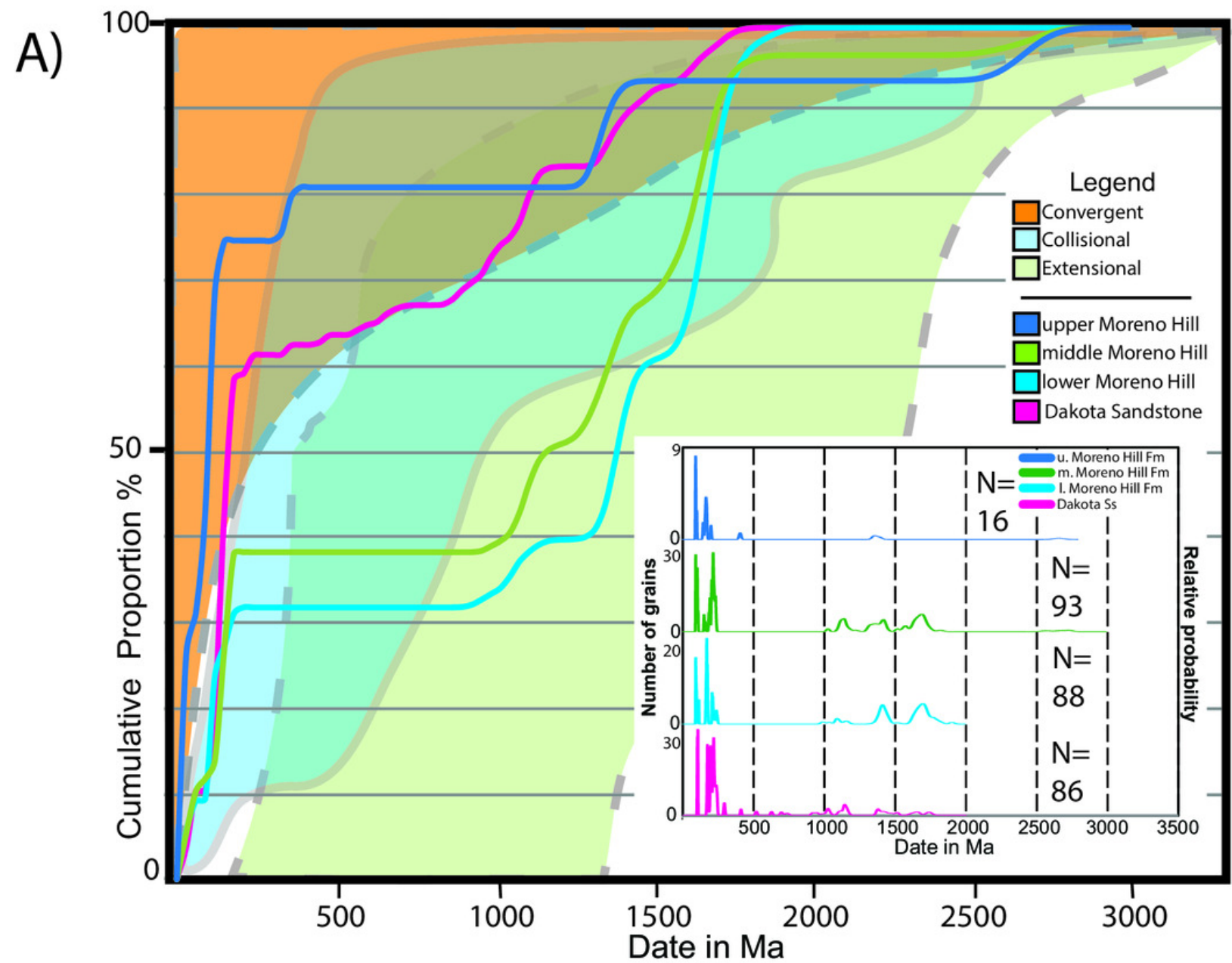

B)

All Grain

\begin{tabular}{|r|c|c|c|c|}
\cline { 2 - 5 } \multicolumn{1}{c|}{ Ages } & Dakota & I. Moreno Hill & m. Moreno Hill & u. Moreno Hill \\
\hline Dakota & & 0.000 & 0.000 & 0.003 \\
\cline { 2 - 5 } I. Moreno Hill & 0.000 & & 0.220 & 0.003 \\
\cline { 2 - 5 } m. Moreno Hill & 0.000 & 0.220 & & 0.001 \\
\cline { 2 - 5 } u. Moreno Hill & 0.003 & 0.003 & 0.001 & \\
\hline
\end{tabular}

Mesozoic

C)

\begin{tabular}{|r|c|c|c|c|}
\cline { 2 - 5 } \multicolumn{1}{c|}{ Grains } & Dakota & I. Moreno Hill & m. Moreno Hill & u. Moreno Hill \\
\hline Dakota & & 0.004 & 0.790 & 0.002 \\
\cline { 2 - 5 } I. Moreno Hill & 0.004 & & 0.019 & 0.211 \\
\cline { 2 - 5 } m. Moreno Hill & 0.790 & 0.019 & & 0.006 \\
\cline { 2 - 5 } u. Moreno Hill & 0.002 & 0.211 & 0.006 & \\
\hline
\end{tabular}

\begin{tabular}{l} 
Moreno Hill \\
\cline { 2 - 4 } \begin{tabular}{c} 
Only \\
\cline { 2 - 4 }
\end{tabular} \\
\begin{tabular}{|c|c|c|c|} 
I. Moreno Hill & I. Moreno Hill & m. Moreno Hill & u. Moreno Hill \\
\cline { 2 - 4 } m. Moreno Hill & 0.220 & 0.220 & 0.003 \\
\cline { 2 - 4 } \\
u. Moreno Hill & 0.003 & 0.001 & 0.001 \\
\hline
\end{tabular}
\end{tabular}




\section{Figure 8}

Sedimentation and zircon input

Plot displays temporal relationship between crystallization age and the delayed depositional input. Due to the similarity of the lower and middle Moreno Hill, this study finds evidence for a singular, longer-lived pulse of sediment input. Thereafter, a second phase with more youthful zircons, and a varied zircon history thus indicates a potential new subdivision of the Moreno Hill Formation into lower and upper members only. K-S analysis after Barbeau et al., 2009b. 

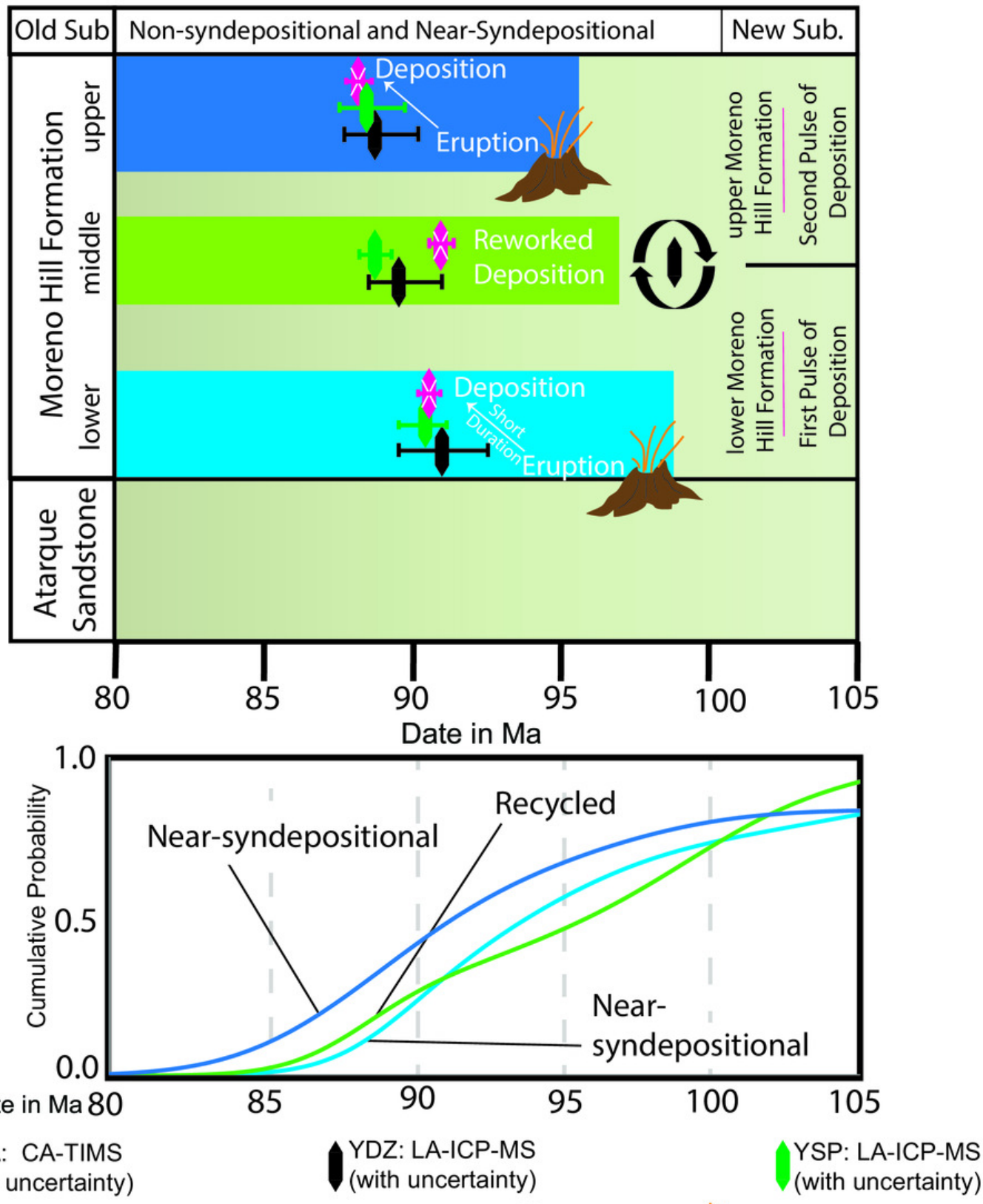

(with uncertainty)

(with uncertainty)

u. Moreno Hill Fm

I. Moreno Hill Fm Detrital/

Near-

m. Moreno Hill Fm 


\section{Figure 9}

Reconstruction of the Moreno Hill depo-center

(A) Emplacement of the alluvial Dakota Sandstone after 96 Ma during the Mowry-Graneros

Seaway with sediment transported via northeasterly draining fluvial systems. (B)

Emplacement of sediment in the lower and middle Moreno Hill Formation, with youthful detrital zircons from the Cordilleran Arc accompanied by sediment and historical zircon populations from the Mogollon Highlands, along with surrounding (reworked) sedimentary blanket southeast of the Sevier Highlands and north of the Mogollon Highlands into the Gallup Delta. (C) Emplacement of sediment into the upper Moreno Hill depo-center with similar source terranes to the underlying units; yet, with the eastward migrating forebulge it is less likely the Sevier and its eastwardly adjacent sedimentary blanket to be a prominent source (now within the north-trending foredeep). Geophysical / paleogeographic maps are based on a synthesis of sources, namely Blakey (2014); Pecha et al. (2018); Lin, Bhattacharya \& Stockford, 2019; Miall \& Catuneanu (2019); Tucker et al. (2020); and references therein. 


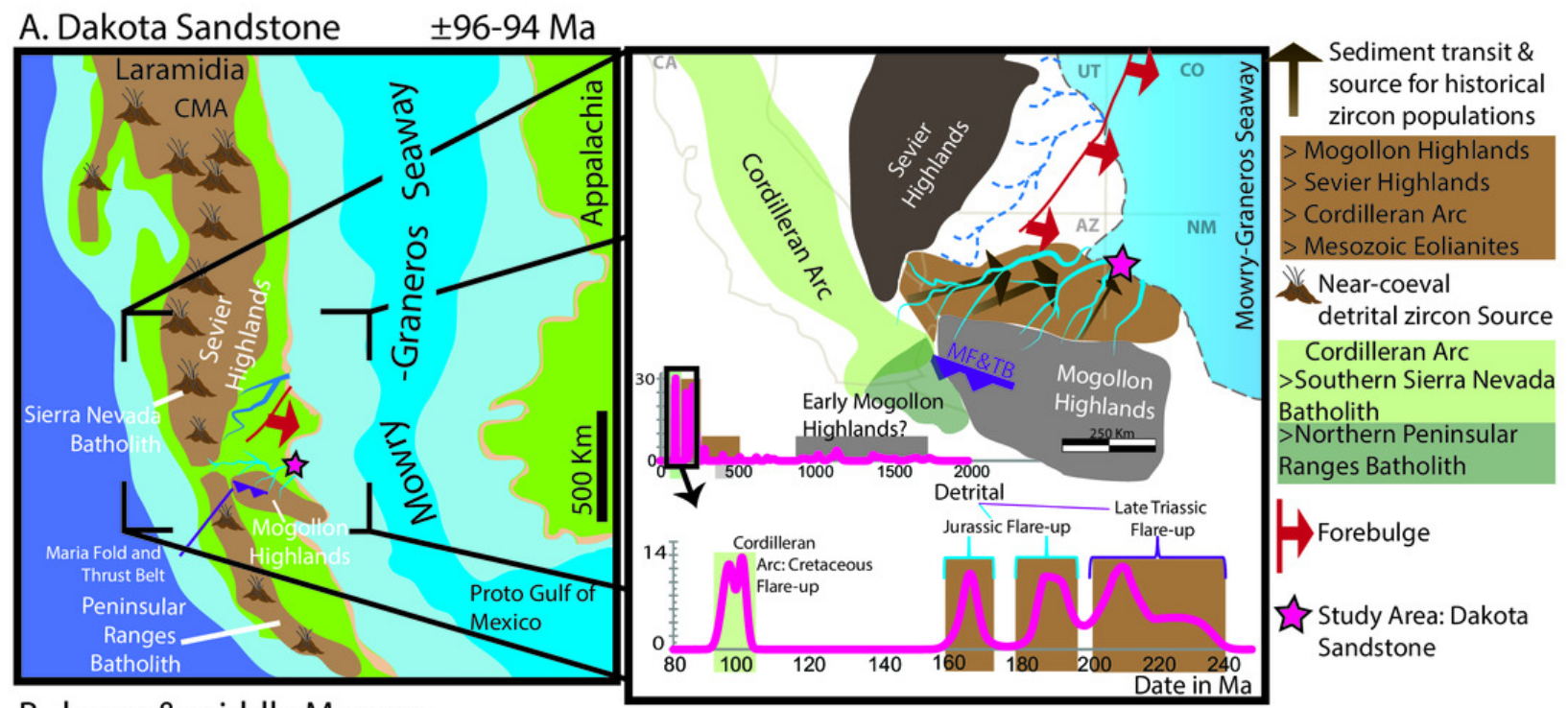

\section{B. lower \& middle Moreno}

\section{Hill Fm $\quad \pm 88 \mathrm{Ma}<\mathrm{n}< \pm 90 \mathrm{Ma}$}

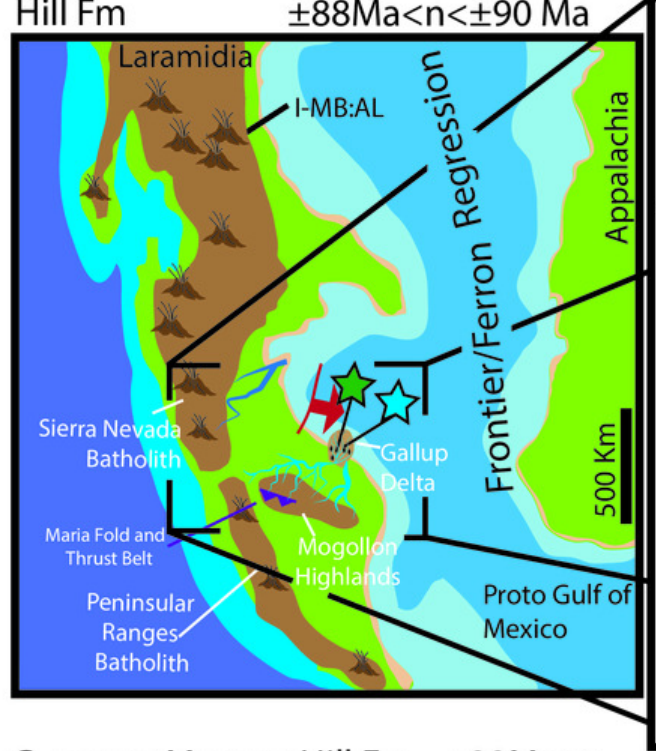

C. upper Moreno Hill Fm $\quad \pm 88 \mathrm{Ma}>\mathrm{n}$
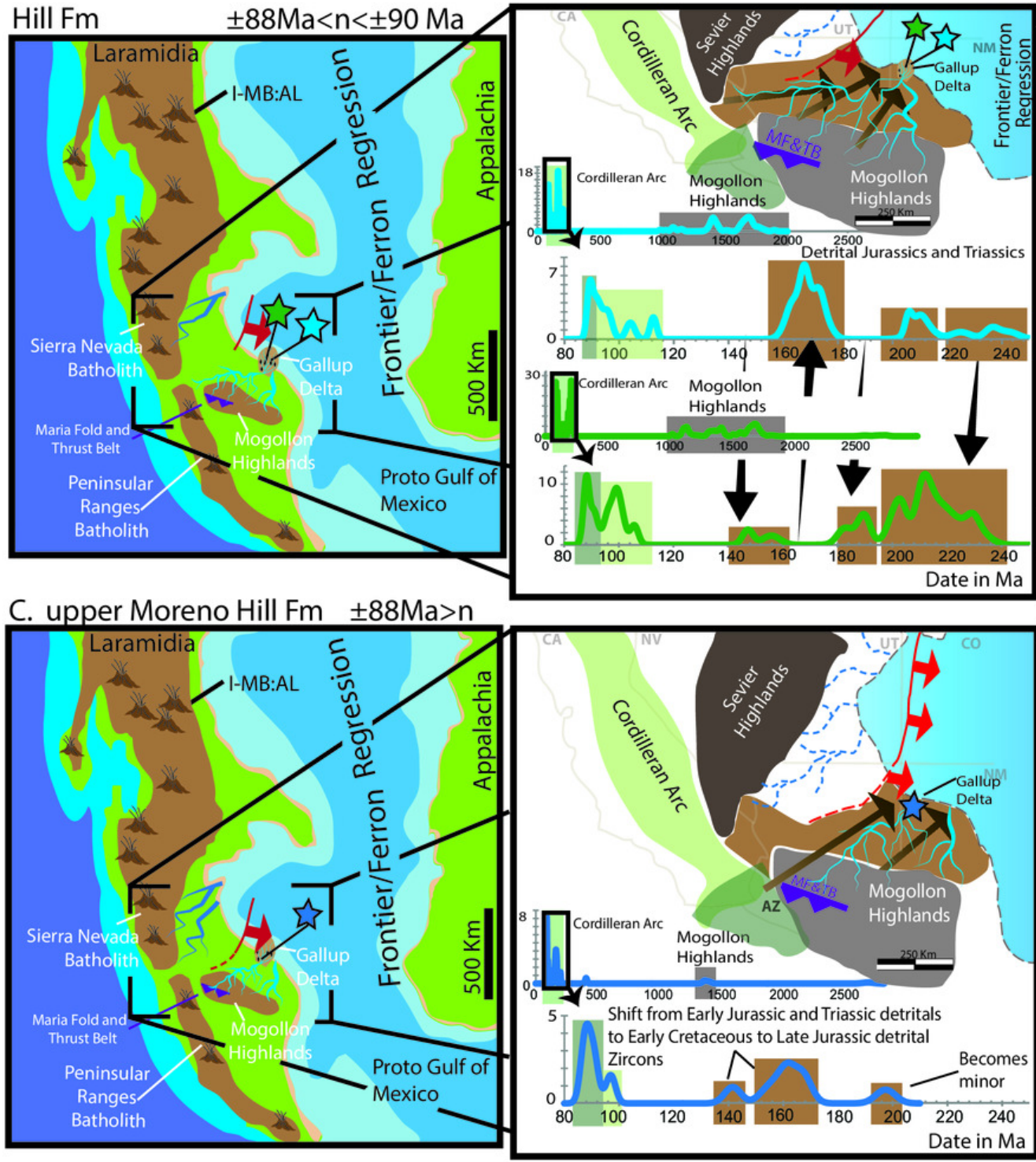
- Sediment transit \& source for historical zircon populations $>$ Mogollon Highlands
$>$ Sevier Highlands
$>$ Cordilleran Arc
$>$ Mesozoic Eolianites
N) Near-coeval detrital zircon Source Cordilleran Arc $>$ Southern Sierra Nevada Batholith $>$ Northern Peninsular Ranges Batholith Forebulge
middle Moreno Hill Fm
lower Moreno $\varpi$ Hill Fm Shifting detrital zircon sources

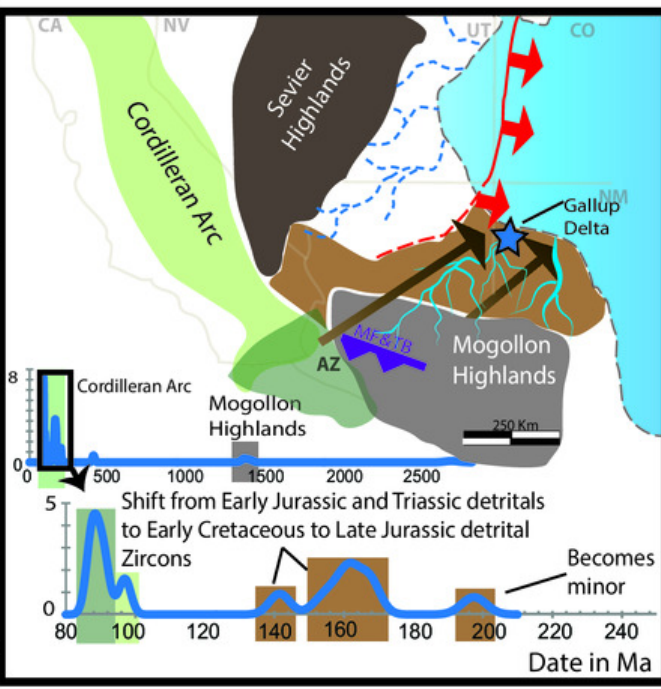

Sediment transit \& source for historical zircon populations $>$ Mogollon Highlands $>$ Sevier Highlands $>$ Cordilleran Arc $>$ Mesozoic Eolianites

Near-coeval detrital zircon Source Cordilleran Arc $>$ Southern Sierra Nevada Batholith $>$ Northern Peninsular Ranges Batholith

17 Forebulge $\leadsto$ upper Moreno Hill Fm 
Table $\mathbf{1}$ (on next page)

$\mathrm{U} / \mathrm{Pb}$ CA-TIMS isotopic data $\mathrm{Pb} / \mathrm{U}$

MDAs via youthful detrital zircons. 


\begin{tabular}{|c|c|c|c|c|c|c|c|c|c|c|c|c|c|c|c|c|c|c|c|c|c|}
\hline \multirow[b]{2}{*}{ Sample } & \multirow[b]{2}{*}{$\begin{array}{l}\text { LA- } \\
\text { ICPMS }\end{array}$} & \multirow[b]{2}{*}{$\frac{T h}{U}$} & \multirow[b]{2}{*}{$\begin{array}{c}{ }^{206} \mathrm{~Pb}^{*} \\
\mathrm{x} 10^{-13} \\
\mathrm{~mol}\end{array}$} & \multirow[b]{2}{*}{$\mathrm{mol} \%$} & \multirow[b]{2}{*}{$\underline{\mathrm{Pb}^{*}}$} & \multirow[b]{2}{*}{$\begin{array}{l}\mathrm{Pb}_{\mathrm{c}} \\
(\mathrm{pg})\end{array}$} & \multirow[b]{2}{*}{$\frac{{ }^{206} \mathrm{~Pb}}{{ }^{204} \mathrm{~Pb}}$} & \multicolumn{8}{|c|}{ Radiogenic Isotope Ratios } & \multicolumn{6}{|c|}{ Isotopic Dates } \\
\hline & & & & & & & & $\frac{{ }^{208} \mathrm{~Pb}}{{ }^{206} \mathrm{~Pb}}$ & $\frac{{ }^{207} \mathrm{~Pb}}{{ }^{206} \mathrm{~Pb}}$ & $\%$ err & $\frac{{ }^{207} \mathrm{~Pb}}{{ }^{235} \mathrm{U}}$ & $\%$ err & $\frac{{ }^{206} \mathrm{~Pb}}{{ }^{238} \mathrm{U}}$ & $\%$ err & $\begin{array}{l}\text { corr. } \\
\text { coef. }\end{array}$ & $\frac{{ }^{207} \mathrm{~Pb}}{{ }^{206} \mathrm{~Pb}}$ & \pm & $\frac{{ }^{207} \mathrm{~Pb}}{{ }^{235} \mathrm{U}}$ & \pm & $\frac{{ }^{206} \mathrm{~Pb}}{{ }^{238} \mathrm{U}}$ & \pm \\
\hline (a) & label & (b) & (c) & (c) & (c) & (c) & (d) & (e) & (e) & $(\mathrm{f})$ & (e) & $(\mathrm{f})$ & (e) & $(\mathrm{f})$ & & $(\mathrm{g})$ & (f) & $(\mathrm{g})$ & $(\mathrm{f})$ & $(\mathrm{g})$ & $(\mathrm{f})$ \\
\hline \multicolumn{22}{|c|}{ MHL-Cox 2} \\
\hline $\mathrm{z} 1$ & 144 & 0,971 & 0,2723 & $99,25 \%$ & 44,5 & 0,17 & 2392 & 0,311 & 0,047845 & 0,303 & 0,094027 & 0,321 & 0,014260 & 0,053 & 0,422 & 90,54 & 7,18 & 91,25 & 0,28 & 91,275 & 0,048 \\
\hline z2 & 145 & 0,513 & 0,2190 & $99,45 \%$ & 54,5 & 0,10 & 3279 & 0,164 & 0,048009 & 0,226 & 0,093912 & 0,244 & 0,014194 & 0,045 & 0,496 & 98,63 & 5,33 & 91,14 & 0,21 & 90,855 & 0,040 \\
\hline \multicolumn{22}{|c|}{ MHM-Cox 3} \\
\hline $\mathrm{z} 1$ & 262 & 0,438 & 0,3606 & $99,52 \%$ & 61,7 & 0,14 & 3789 & 0,140 & 0,048001 & 0,198 & 0,102478 & 0,210 & 0,015491 & 0,051 & 0,343 & 98,25 & 4,69 & 99,06 & 0,20 & 99,095 & 0,051 \\
\hline $\mathrm{z} 2$ & 263 & 1,472 & 0,2384 & $99,49 \%$ & 74,4 & 0,10 & 3566 & 0,471 & 0,047968 & 0,229 & 0,094457 & 0,248 & 0,014288 & 0,047 & 0,483 & 96,65 & 5,43 & 91,65 & 0,22 & 91,454 & 0,043 \\
\hline \multicolumn{22}{|c|}{ MHU-Cox 4} \\
\hline z2 & 33 & 0,503 & 0,1096 & $98,88 \%$ & 26,6 & 0,10 & 1618 & 0,161 & 0,048049 & 1,003 & 0,097621 & 1,064 & 0,014742 & 0,152 & 0,464 & 100,64 & 23,71 & 94,58 & 0,96 & 94,338 & 0,142 \\
\hline zla & 17 & 0,562 & 0,0828 & $98,15 \%$ & 16,2 & 0,13 & 978 & 0,180 & 0,047993 & 0,755 & 0,091585 & 0,796 & 0,013847 & 0,084 & 0,525 & 97,87 & 17,86 & 88,98 & 0,68 & 88,648 & 0,074 \\
\hline $\mathrm{zlb}$ & 17 & 0,627 & 0,0767 & $89,79 \%$ & 2,7 & 0,72 & 177 & 0,201 & 0,048354 & 2,643 & 0,092014 & 2,779 & 0,013808 & 0,326 & 0,465 & 115,55 & 62,31 & 89,38 & 2,38 & 88,401 & 0,286 \\
\hline
\end{tabular}

(a) z1, z2, etc. are labels for analyses composed of single zircon grains that were annealed and chemically abraded (Mattinson, 2005). z1a and z1b are fragments from the same grain.

(b) Model $\mathrm{Th} / \mathrm{U}$ ratio calculated from radiogenic $208 \mathrm{~Pb} / 206 \mathrm{~Pb}$ ratio and $207 \mathrm{~Pb} / 235 \mathrm{U}$ date.

(c) $\mathrm{Pb} *$ and $\mathrm{Pbc}$ are radiogenic and common $\mathrm{Pb}$, respectively. mol \% ${ }^{206} \mathrm{~Pb} *$ is with respect to radiogenic and blank $\mathrm{Pb}$.

(d) Measured ratio corrected for spike and fractionation only. Fractionation correction for single-collector Daly analyses is based on measurement of $202 \mathrm{~Pb} / 205 \mathrm{~Pb}$ in the EARTHTIME ET2535 tracer solution.

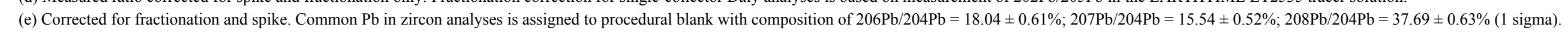
$206 \mathrm{~Pb} / 238 \mathrm{U}$ and $207 \mathrm{~Pb} / 206 \mathrm{~Pb}$ ratios corrected for initial disequilibrium in $230 \mathrm{Th} / 238 \mathrm{U}$ using a $\mathrm{D}(\mathrm{Th} / \mathrm{U})$ of $0.20 \pm 0.05$ (1 sigma).

(f) Errors are 2 sigma, propagated using algorithms of Schmitz and Schoene (2007) and Crowley et al. (2007).

(g) Calculations based on the decay constants of Jaffey et al. (1971). 206 Pb/238U and 207Pb/206Pb dates corrected for initial disequilibrium in $230 \mathrm{Th} / 238 \mathrm{U}$ using a $\mathrm{D}(\mathrm{Th} / \mathrm{U})$ of $0.20 \pm 0.05(1 \mathrm{sigma})$.

1 


\section{Table 2 (on next page)}

Comparison of different LA-ICPMS-MDA metrics

Comparison of five (5) different metrics utilized within this study to interpret the Maximum Depositional Age (MDAs) for each detrital sample (modified from Tucker et al. [2013, 2016]; Coutts et al. [2019]; Herriott et al. [2019]; Tucker et al. [2020]). YDZ, Weighted Average and TuffZirc were run via Isoplot 4.15 (Ludwig, 2003), YC2 $\sigma$ via Age Pick Program (2010) G. Gehrels 1 September 2009, Arizona Laserchron Center, and YSP via Herriott et al. (2019). 


\begin{tabular}{|c|c|c|c|c|c|}
\hline \multicolumn{2}{|c|}{ Analysis } & \multirow{2}{*}{$\begin{array}{c}\begin{array}{c}\text { Dakota } \\
\text { Sandstone }\end{array} \\
96.12\end{array}$} & \multirow{2}{*}{$\begin{array}{c}\begin{array}{c}\text { Lower } \\
\text { Moreno } \\
\text { Hill }\end{array} \\
91.16\end{array}$} & \multirow{2}{*}{$\begin{array}{c}\begin{array}{c}\text { Middle } \\
\text { Moreno } \\
\text { Hill }\end{array} \\
89.5 \\
\end{array}$} & \multirow{2}{*}{$\begin{array}{c}\begin{array}{c}\text { Upper } \\
\text { Moreno } \\
\text { Hill }\end{array} \\
89.3\end{array}$} \\
\hline YDZ (N=6) & Final Age & & & & \\
\hline & Range & $+1.6 /-2.0$ & $+2.5 /-2.1$ & $+3.1 /-1.8$ & $+3.4 /-2.4$ \\
\hline & Confidence & $95 \%$ & $95 \%$ & $95 \%$ & $95 \%$ \\
\hline \multirow{5}{*}{$\begin{array}{c}\text { WEIGHTED } \\
\text { AVERAGE } \\
(\mathrm{N}=6)\end{array}$} & Final Age & $96.5( \pm 1.6)$ & $\begin{array}{c}91.4 \\
( \pm 2.9)\end{array}$ & $90.2( \pm 3.7)$ & $90.5( \pm 4.9)$ \\
\hline & Confidence & $95.0 \%$ & $95.0 \%$ & $95.0 \%$ & $95.0 \%$ \\
\hline & Rejection & 0 & 0 & 0 & 0 \\
\hline & MSWD & 1.2 & 4.2 & 7.9 & 5.1 \\
\hline & Probability & 0.30 & 0.0 & 0.0 & 0.0 \\
\hline \multirow[t]{4}{*}{$\begin{array}{l}Y C 2 \sigma \\
(N=6)\end{array}$} & Final Age & $\begin{array}{c}96.5 \\
\pm 2.5(2.6 \%)\end{array}$ & $\begin{array}{c}90.2 \\
\pm 2.3(2.5 \%)\end{array}$ & $\begin{array}{c}89.1 \\
\pm 2.5(2.8 \%)\end{array}$ & $\begin{array}{c}90.5 \\
\pm 3.3(3.6 \%)\end{array}$ \\
\hline & $\begin{array}{l}\text { Weighted } \\
\text { Mean Age }\end{array}$ & $\begin{array}{c}96.5 \\
\pm 2.3(2.4 \%)\end{array}$ & $\begin{array}{c}90.2 \\
\pm 2.1(2.3 \%)\end{array}$ & $\begin{array}{c}89.1 \\
\pm 2.2(2.5 \%)\end{array}$ & $\begin{array}{c}90.5 \\
\pm 3.1(3.4 \%)\end{array}$ \\
\hline & $\begin{array}{r}\text { Systematic } \\
\text { Error }\end{array}$ & $1.1 \%$ & $1.1 \%$ & $1.1 \%$ & $1.1 \%$ \\
\hline & MSWD & 0.3 & 2.0 & 0.0 & 1.3 \\
\hline \multirow{4}{*}{$\begin{array}{l}\text { TUFF ZIRC } \\
(\mathrm{N}=6)\end{array}$} & & 96.32 & 91.69 & 89.36 & 89.01 \\
\hline & Age & $\begin{array}{c}+3.19 /- \\
1.81 \\
\end{array}$ & $\begin{array}{c}+3.02 /- \\
2.42\end{array}$ & $\begin{array}{c}+1.49 /- \\
1.79\end{array}$ & $\begin{array}{c}+1.69 /- \\
1.81\end{array}$ \\
\hline & Confidence & $96.6 \%$ & 93.8 & $87.6 \%$ & $87.6 \%$ \\
\hline & Group Size & 6 of 6 & 5 of 6 & 4 of 6 & 4 of 6 \\
\hline \multirow[t]{3}{*}{ YSP } & Final Age & 95.19 & 90.21 & 88.67 & 88.82 \\
\hline & Error $( \pm 2 \sigma)$ & $\pm 0(1.26)$ & $\pm 1.2(1.65)$ & $\pm 1.1(1.52)$ & $\pm 1.7(2.1)$ \\
\hline & MSDW & 0.96 & 1.19 & 1.38 & 0.94 \\
\hline
\end{tabular}




\begin{tabular}{|c|c|c|c|c|c|}
\hline & PoF & .46 & .312 & .247 & .418 \\
\hline Average & & $\mathbf{9 6 . 1} \mathbf{~ M a}$ & $\mathbf{9 0 . 9} \mathbf{~ M a}$ & $\mathbf{8 9 . 3} \mathbf{M a}$ & $\mathbf{8 9 . 6} \mathbf{M a}$ \\
\hline
\end{tabular}

